This is the final pre-publication version of an article submitted to Economics and Human

Biology in April 2017

Published details:

Alan Sánchez (2017) 'The structural relationship between early nutrition, cognitive skills and non-cognitive skills in four developing countries', in Economics \& Human Biology, Volume 27, Part A, November 2017, Pages 33-54

\title{
The structural relationship between early nutrition, cognitive skills and non-cognitive skills in four developing countries
}

\author{
Alan Sánchez* \\ March 21, 2017
}

\begin{abstract}
This study provides evidence about how cognitive and non-cognitive skills are acquired during childhood in four developing countries (Ethiopia, India, Peru and Vietnam), highlighting the role of early nutrition as a determinant in this process. An increase of one standard deviation in height-for-age at the age of 1 is found to have a total effect on cognitive skills at age 8 by 5.4 percent in Ethiopia, 9.0 percent in India, 7.6 percent in Peru and 8.4 percent in Vietnam. The corresponding total effect on non-cognitive skills is 1.1 percent in Ethiopia, 3.4 percent in India, 2.6 percent in Peru and 1.7 percent in Vietnam. The evidence suggests the effect of early nutrition on non-cognitive skills is indirect, mediated by cognitive skills. The effect is also relatively small in magnitude.
\end{abstract}

JEL codes: I1, I2. Keywords: Early childhood development; Nutrition; Skills; Children

\section{Introduction}

\footnotetext{
* Grupo de Análisis para el Desarrollo, Av. Grau 915, Lima 4, Peru. Corresponding email address: asanchez@grade.org.pe. I am grateful to Guido Melendez and Nicolas Pazos for superb research assistance. I thank Jere Behrman, Janos Gabler and participants at seminars in Oxford and Lima for providing comments on an earlier version of this paper. All errors and inaccuracies are my responsibility. The data used are from the Young Lives study. Young Lives is core-funded from 2001 to 2017 by UK aid from the Department for International Development (DFID), and co-funded by IrishAid from 2014 to 2015.
} 
Stunting in young children is a persistent phenomenon in developing countries. Globally, 23.2 percent of children under 5 years of age were stunted in $2015^{1}$. While this represents a decline compared to the 2000 figure (32.7 percent), progress has been uneven around the world, with five sub-regions still reporting stunting rates above 30 percent (Western Africa, Middle Africa, Eastern Africa, Southern Asia, and Oceania). Stunting is associated with under nutrition and is considered one of the main risk factors for sub-optimal child development (Grantham-McGregor et al., 2007). Accordingly, its eradication is a prominent feature of the 2030 agenda for sustainable development.

This study aims to expand our understanding of the role of early undernutrition in the formation of skills, going beyond the well-known impact on cognitive skills (Alderman et al., 2006; Glewwe et al., 2001). There is some evidence to suggest the existence of a link between early nutrition and behaviour. Grantham-McGregor et al. (1999) summarize results from early studies that assess behavioural dimensions of mildly to moderately underweight infants or school-aged children who were also stunted. According to these findings, underweight children were more anxious and less environmentally involved than children of normal weight, and children who were stunted between 9 and 24 months of age had lower activity levels than non-stunted children, explored their environment with less enthusiasm than those children and were less happy than them. Other studies look at the impact of clinical malnutrition on behaviour. Grantham-McGregor (1995) presents a review of this evidence. She finds that formerly severely malnourished children had behavioural problems similar to those mentioned above, as well as lower psychological functioning. For a recent study on the impact of clinical malnutrition, see Galler et al. (2012).

Arguably, the most compelling evidence about the relationship between early stunting and non- cognitive skills comes from a cohort study in Jamaica. Chang et al. (2002) show that children who were stunted in the first two years of life reported lower psychological functioning at age 11, compared to those that were not. Similar evidence is observed at age 17 (Walker et al., 2007). These differences included lower self-esteem, more anxiety, depressive symptoms, and anti-social behaviour.

A relationship between early stunting and non-cognitive skills is expected, given the nutrition- cognition nexus and the existence of "cross-effects" from cognitive to noncognitive skills (Cunha and Heckman, 2008), which suggests an indirect channel through which this relationship can occur. But there might also be a direct channel in place. Walker et al. (2007) point out that a direct relationship can arise because early malnutrition affects brain structure, leading to lasting cognitive and emotional effects. See also Levitsky and Strupp (1995) and Tierney and Nelson (2009). In addition, when interpreting the results of the pioneer INCAP study in Guatemala (a randomized, nutritional intervention during early infancy), Pollitt et al. (1993) suggest that the effect of malnutrition on motor maturation and exploratory behaviour is what drives the relationship between malnutrition and the acquisition of cognitive abilities and social behaviours, an observation that has been reinforced in more recent studies (Black et al., 2004).

A possible theoretical framework to study the role of early undernutrition on the formation of skills is the technology of skill formation formulated by Cunha and Heckman (2008).

\footnotetext{
${ }^{1}$ Official estimates from UNICEF/World Health Organization/World Bank joint report.
} 
This model highlights the notions that skills are self-reinforcing (self-productivity) and that cognitive skills are an input for non-cognitive skills, and vice versa (cross-productivity). In turn, the whole process is driven by parental investments, which feed both types of skills at different stages of childhood and adolescence. The authors formulate and estimate this model using panel data from the United States. Although this framework is useful for conceptualizing the process of skill accumulation, early nutritional status is not used as an input in the model. Two subsequent studies, which use data from the Young Lives longitudinal study, go further in this direction (Helmers and Patnam, 2011; Dercon and Sanchez, 2013). The first study cited estimates the skill formation model for India, while the second one uses a reduced-form approach to look at the relationship between heightfor-age at the age of 8 and psychosocial competencies at the age of 12 in four developing countries. Owing to data constraints, neither of these studies was able to trace the link between early nutrition and non-cognitive skills (in the Young Lives study, the collection of indicators of non-cognitive skills for those children followed since birth took place in Round 3 of the survey, and these studies used data from the first two rounds only). Within this context, the objective of this study is twofold. First, to test the role of early undernutrition in the formation of cognitive and non-cognitive skills in developing countries using an extended version of the skill formation model in which nutritional status is allowed to play a role. Second, to analyse the mechanisms through which such relationship emerges. To achieve these objectives I use data from the first three rounds of Young Lives, a longitudinal study that tracks the lives of 12,000 children in a group of countries ranging from low-income (Ethiopia) to lower-middle-income (India) and uppermiddle-income (Vietnam and Peru). For each country sample, I estimate a structural model in which height-for-age at ages 1 and 5 is an input for cognitive skills at ages 5 and 8 , and for cognitive and non-cognitive skills at age 8 . This rich international data set allows me to deal with measurement error and endogeneity issues, while the fact that data are available for four countries makes it possible to discuss the external validity of the results.

\section{The data}

Young Lives is a longitudinal study of childhood poverty that is collecting data on 12,000 children in Ethiopia, India (undivided Andhra Pradesh) ${ }^{2}$, Peru and Vietnam. These four countries were selected to reflect a range of cultural, economic, geographical, political and social contexts, as well as common issues faced by developing countries. At the beginning of the study, Ethiopia, India and Vietnam were classified by the World Bank as low-income countries, whereas Peru was classified as a lower-middle-income country. Since then, Peru and Vietnam and, to a certain extent, India, have experienced sustained periods of economic growth. Currently Peru and Vietnam are classified as upper-middle-income countries, while India is considered a lower-middle-income economy.

Two birth cohorts are tracked in each country: a Younger Cohort, born in 2001/2; and an Older Cohort, born in 1994/5. This study uses data from the Younger Cohort. Children in the Younger Cohort have been visited in four rounds. Round 1 was administered in 2002, when the children were about 1 year old (between 6 and 18 months). Three additional

\footnotetext{
${ }^{2}$ The state of Andhra Pradesh was bifurcated into the two new states of Telangana and Andhra Pradesh on 2 June 2014.
} 
survey rounds took place in 2006, 2009 and 2012, when ages were 5, 8 and 12 years, respectively. This study uses data from the first three rounds. In each country, approximately 2,000 children were sampled following using a multi-stage sampling procedure $^{3}$. These country samples are not nationally representative. In fact, Young Lives purposively drew up pro-poor samples. Despite this, it has been found that the samples reflect the diversity of living conditions existent in each country (Outes and Sanchez, 2008; Kumra, 2008; Escobal and Flores, 2008; Nguyen, 2008). It is worth to noting that attrition levels in the first three survey rounds were below 5 percent in all cases $(2.2$ percent in Ethiopia, 2.2 percent in India, 4.4 percent in Peru and 2.0 percent in Vietnam), which is relatively low compared to attrition levels in other longitudinal studies in developing countries (Dercon and Outes-Leon, 2008).

Table 1: Key summary statistics by country sample (mean)

\begin{tabular}{lcccc}
\hline & Ethiopia & India & Peru & Vietnam \\
\hline Rural households (\%) & 63 & 76 & 31 & 83 \\
Maternal education (\%) & & & & \\
$\quad$ None & 50 & 50 & 8 & 9 \\
$\quad$ Primary education only & 11 & 28 & 36 & 26 \\
$\quad$ Secondary education or higher & 47 & 47 & 56 & 65 \\
Female children (\%) & 30 & 19 & 16 & 49 \\
Child stunted at age 1 (\%) & 30 & 33 & 30 & 23 \\
Child stunted at age 5 (\%) & 1440 & 1676 & 1661 & 1407 \\
\hline Number of observations & &
\end{tabular}

Note: Sample size corresponds to the balanced sample of children observed during the first survey round with non-missing values in the variable used for the estimations. Primary education level includes adult literacy programmes.

Key demographic characteristics by country sample are reported in Table 1. The information corresponds to household characteristics observed during Round 1 of the survey in 2002. Among the four country samples, Peru has the lowest proportion of rural households, which, in turn, reflects differences in the degree of urbanization at the national level ${ }^{4}$. Respondents in Peru and Vietnam reported the highest levels of maternal education. Despite this, stunting levels are not remarkably different across the country samples. By age 1, stunting levels were especially high in Ethiopia, however by age 5 differences across the countries had diminished drastically. In fact, stunting levels by age 5 were the same in Peru and Ethiopia, at around 30 percent. This result is probably a reflection of the high levels of inequality observed in Peru at the national level, which is

3 In each country, 20 clusters were selected. Then, within each cluster 100 households with a child aged between 6 and 18 months were selected at random to participate in the study, creating cohorts of up to 2,000 children in each country. More details of the sample design can be found in Outes and Sanchez (2008) for Ethiopia, Kumra (2008) for India, Escobal and Flores (2008) for Peru, and Nguyen (2008) for Vietnam.

${ }^{4}$ According to the World Bank, the proportion of rural households in Ethiopia, India, Peru and Vietnam in 2002 was 85 percent, 72 percent, 27 percent and 75 percent respectively (World Bank Indicators). 
reflected in the Peru Young Lives sample. For a comparison with the proportion of stunted children in developed countries, see Albertsson-Wikland and Karlberg (1995).

\section{The model}

The objective is to estimate a linear version of the skill formation model (Cunha and Heckman, 2007), extended to take into account the role of early nutrition. Essential features of this model are that more skills accumulated in the present period lead to more skills accumulated in the next period (self-productivity); that cognitive skills reinforce noncognitive skills, and vice versa (cross-productivity); and, ultimately, that skills are shaped by parental investments. Within this framework, I introduce nutritional status as an additional input for cognitive and non-cognitive skills. In turn, nutritional status can be affected by lagged skills, lagged nutrition, and parental investments in nutrition. Anticipating the characteristics of the data available, a model in which children are observed at ages 1, 5 and 8 is proposed. Cognitive skills, non-cognitive skills and nutritional status at age 8 are denoted as $\theta_{8 y}^{C}, \theta_{8 y}^{N}$ and $H_{8 y}$ (respectively). Similarly, $\theta_{5 y}^{C}$ and $H_{5 y}$ denote cognitive skills and nutritional status at age 5, while parental investments in skills and nutrition at age 8 are denoted as $I_{8 y}$ and $I_{8 y}^{H}$. Considering these variables, the following set of linear equations is proposed,

$$
\begin{aligned}
& \theta_{8 y}^{C}=\beta_{11}+\beta_{12} I_{8 y}+\beta_{13} H_{5 y}+\beta_{14} \theta_{5 y}^{C}+X \Theta_{15 y}+\varepsilon_{1} \\
& \theta_{8 y}^{N}=\beta_{21}+\beta_{22} I_{8 y}+\beta_{23} H_{5 y}+\beta_{24} \theta_{5 y}^{C}+X \Theta_{25 y}+\varepsilon_{2} \\
& H_{8 y}=\beta_{31}+\beta_{32} I_{8 y}^{H}+\beta_{33} H_{5 y}+\beta_{34} \theta_{5 y}^{C}+X \Theta_{35 y}+\varepsilon_{3}
\end{aligned}
$$

Besides the variables of interest, each equation includes a vector (X) that takes into account five exogenous characteristics: whether the child was born in a rural area, the household's geographical location using country-specific dummy variables ${ }^{5}$, mother's years of education and whether the child was born in 2002 (as opposed to 2001). In all equations, $\varepsilon$ stand for the error term. In turn, $\theta_{5 y}^{C}$ and $H_{5 y}$ are assumed to be a function of nutritional status at age $1\left(H_{1 y}\right)$ and parental investments in skills and nutrition at age $5\left(I_{5 y}\right.$ and $I_{5 y}^{H}$, respectively), as follows,

$$
\begin{aligned}
& \theta_{5 y}^{C}=\beta_{41}+\beta_{42} I_{5 y}+\beta_{43} H_{1 y}+X \Theta_{45 y}+\varepsilon_{4} \\
& H_{5 y}=\beta_{51}+\beta_{52} I_{5 y}^{H}+\beta_{53} H_{1 y}+X \Theta_{55 y}+\varepsilon_{5}
\end{aligned}
$$

\footnotetext{
${ }^{5}$ Geographical regions were defined according to the information available in Round 1 of the Young Lives survey, as follows: Addis Ababa, Amhara, Oromia, SNNP and Tigray in Ethiopia; Coastal Andhra, Rayalaseema and Telangana in India; Coast, Highlands and Jungle in Peru; and, Northern Uplands, Red River Delta, Central Coastal and Mekong River Delta in Vietnam.
} 
This structure can be used to trace the impact of early nutritional status on skills. In particular, nutritional status at age 1 can affect skills in subsequent periods through direct and indirect channels. At the same time, the model is consistent with findings from the skills formation literature (Todd and Wolpin, 2003; Cunha and Heckman, 2007; Cunha et al., 2010).

One caveat of the proposed model specification is that non-cognitive skills at age 5 do not play a role. This reflects a data limitation, in the sense that the instruments used to measure non-cognitive skills in the Young Lives study cannot be applied to very young children, because these data are self-reported. Considering that our interest lies in calculating the impact of nutrition at age 1 on skills, this potentially generates a bias in our predictions. Within the current structure, the total effect of height at age 1 on cognitive skills at age 8 is given by $\beta_{13} \beta_{53}+\beta_{14} \beta_{43}$, and the corresponding total effect on non-cognitive skills is given by $\beta_{23} \beta_{53}+\beta_{24} \beta_{43}$. Yet since nutrition at age 1 could also affect non-cognitive skills at age 5, and this, in turn, could affect skills at age 8, the total effects that I am able to compute are likely to represent a lower bound of the true total effect.

\section{$4 \quad$ Estimation of the model}

In the model expressed in Equations 1 to 5, nutritional status $\left(H_{1 y}, H_{5 y}\right.$ and $\left.H_{8 y}\right)$ is proxied by a child's height-for-age z-score, which is calculated using the most recent growth standards of the World Health Organization (WHO). Cognitive $\operatorname{skills}\left(\theta_{8 y}^{C}, \theta_{5 y}^{C}\right)$, noncognitive skills $\left(\theta_{8 y}^{N}\right)$, and parental investments $\left(I_{5 y}^{H}, I_{5 y}, I_{8 y}^{H}, I_{8 y}\right)$ are treated as unobserved latent factors. The fact that multiple cognitive and non-cognitive indicators, as well as resources devoted to the child, are observed in each round of the Young Lives survey is exploited to obtain estimates for each type of latent factor through one-factor linear measurement models. In particular, cognitive skills are measured using a child's scores in vocabulary, reading comprehension and maths tests, whereas non-cognitive skills are measured using a child's results in indicators designed to measure self-esteem and selfefficacy. A precise mapping of how skills and parental investments are related to observed indicators in the Young Lives data is reported in Table 2.

To measure cognitive skills at age 5, I use the Peabody Picture Vocabulary Test (PPVT) and the Quantitative Section of the Cognitive Development Assessment (CDA). The PPVT is a widely used test of receptive vocabulary, in which the level of difficulty varies according to the child's age. The test is composed of up to 204 items (125 in the Hispanic version $)^{6}$. In each item, the interviewer says a word to the child and she must select the picture that best represents the word (out of four possibilities). The CDA is a test designed to measure cognitive development at the pre-school stage. The quantitative section of the CDA (15 items) aims to measure a child's knowledge of notions associated with numeracy (such as few, most, half, many, equal, a pair, etc.). In each item the child is asked to indicate which one of a set of pictures best fits the description provided by the interviewer (out of four possibilities).

When the Younger Cohort was 8 years old, Young Lives replaced the CDA with a mathematics test designed to measure basic quantitative and number notions

\footnotetext{
${ }^{6}$ In Peru, the Hispanic version of the PPVT (PPVT-R) was used, whereas in Ethiopia, India and Vietnam, the English version of the PPVT (PPVT-III) was administered.
} 
(consisting of 29 items). In addition, the Early Grade Reading Assessment (EGRA) was included to test reading and listening comprehension. The EGRA includes a reading comprehension task (where the child is asked to read a short text and then eight questions about the text are posed orally), and a listening comprehension task (where the child is read a text and then six questions are posed orally). Thus, PPVT and CDA scores are used to record cognitive skills at age 5. At age 8, PPVT, EGRA and maths test scores are used for the same purpose. It is worth highlighting that all tests were translated into the main language of each country and piloted and adjusted prior to data collection. In all cases, I use the child's raw score in each test (number of correct answers), with a standardization by country and by age (in years). More information about the tests can be found in Cueto et al. (2009) and Cueto and Leon (2013).

Table 2: Observable variables used for estimation of latent factors

\begin{tabular}{|c|c|c|}
\hline Latent factor & & Observable variable \\
\hline Cognitive skills (age 8) & $\theta_{8 y}^{C}$ & $\begin{array}{l}\text { Peabody Picture Vocabulary Test (PPVT) } \\
\text { Early Grade Reading Assessment (EGRA) } \\
\text { Mathematics test }\end{array}$ \\
\hline Non-cognitive skills (age 8) & $\theta_{8 y}^{N}$ & $\begin{array}{l}\text { Self-esteem score } \\
\text { Self-efficacy score }\end{array}$ \\
\hline Cognitive skills (age 5) & $\theta_{5 y}^{C}$ & $\begin{array}{l}\text { PPVT } \\
\text { Cognitive Development Assessment (CDA) }\end{array}$ \\
\hline Parental investments in skills (age 8) & $I_{8 y}$ & $\begin{array}{l}\text { Log expenditure on children's clothes (per child) } \\
\text { Log expenditure on children's education (per child) } \\
\text { Number of hours child studies outside school } \\
\text { Quality of relationship between child and parents }\end{array}$ \\
\hline Parental investments in skills (age 5) & $I_{5 y}$ & $\begin{array}{l}\text { Log expenditure on children's clothes (per child) } \\
\text { Average number of hours children study outside school }\end{array}$ \\
\hline $\begin{array}{l}\text { Parental investments in nutrition } \\
\text { (age } 5 \text { and } 8 \text { ) }\end{array}$ & $I_{8 y}^{H}, I_{5 y}^{H}$ & $\begin{array}{l}\text { Log consumption of carbohydrates (per capita) } \\
\text { Log consumption of proteins (per capita) } \\
\text { Log consumption of minerals and vitamins (per capita) } \\
\text { Log consumption of lipids and other food types (per } \\
\text { capita) }\end{array}$ \\
\hline
\end{tabular}

To measure non-cognitive skills at age 8 , I use indicators designed to assess dimensions of self- esteem and self-efficacy. The concept of self-esteem is related to a person's overall evaluation of her own worth, whereas self-efficacy is related to a person's sense of mastery or agency over her life. Both qualities have intrinsic value, and have been found to predict school achievement and labour market outcomes (Stajkovic and Luthans, 1998; Trzesniewski et al., 2003; Goldsmith et al., 1997). Moreover, in recent papers that use data from the Older Cohort of Young Lives, low self-esteem scores have been found to predict risky behaviours (Favara and Sanchez, 2017), whereas low self-efficacy predicts teenage pregnancy (Favara et al., 2016).

In the Young Lives study, these traits are assessed on the basis of respondents' degree of agreement or disagreement with a number of statements contained in face-to-face questionnaires. This is measured on a 5-point Likert scale. During administration, the options were represented with sad or happy faces, in order to make the test friendlier for children. The self-esteem scale measures aspects related to pride ${ }^{7}$, and it builds on

\footnotetext{
7 'I am proud of my shoes or of having shoes'; 'I am proud of my clothes'; 'I am never embarrassed because I do not have the right books, pencils or other equipment'; 'I am proud that I have the correct uniform'; 'I am proud of the work I have to do'.
} 
the Rosenberg scale (Rosenberg, 1965). The self-efficacy scale measure aspects related to agency ${ }^{8}$, and it builds on the Rotter scale (Rotter, 1966). Each scale is calculated by obtaining an average score across the non-missing values of the answers. In the case of the self-efficacy indicator, two items are excluded due to negative inter-item correlation ${ }^{9}$. Average scores were standardized within countries. A validation of these indicators can be found in Dercon and Krishnan (2009). It is worth noting that the Spearman's correlation between the self-esteem and self-efficacy indicators is 28 percent in Ethiopia, 37 percent in India, 40 percent in Peru and 29 percent in Vietnam. Summary statistics for these indicators and for the cognitive test scores used are reported in Table 9 (prior to standardization).

An analogous procedure is followed for parental investments. In particular, indicators were selected that contained information about parental resources devoted to the child in terms of money and time. For parental investments in skills at age 8, I use household expenditure on education for children, household expenditure on clothes for children (both expressed in logs, and in per child terms), average number of hours the child spent studying at home (as a proxy for the time that parents dedicated to the child), and an indicator of the quality of the relationship between the child and her parents ${ }^{10}$. For parental investments in skills at age 5, I use the same two variables for household expenditure, as well as average number of hours children in the family spent studying at home (child-specific information about time spent studying was not available in this case). Although there are other observable indicators that are related to parental investments, these indicators were selected because they are observed in all countries. Finally, to measure parental investments in nutrition, food expenditure per capita in four food groups was considered: (i) carbohydrates, (ii) proteins, (iii) vitamins and minerals, (iv) lipids and other food types. Summary statistics are reported in Table 9 (Annex). The exact form of the one-factor linear measurement models for skills and parental investments is reported in the Supplementary Material (Part B). The recovered factors obtained from these equations are plugged into the model expressed in Equations 1 to 5.

Following Cunha and Heckman (2008) and Helmers and Patnam (2011), I calculate the resulting contribution of each factor to explain the variance of each indicator variable in the data (Table 10, Annex). The skills factors explain an important share of the variance of each of the observed indicators (between 35 and 80 percent for the cognitive indicators, and between 25 and 40 for the non-cognitive indicators). Similarly, the factors for parental investments explain an important share of the variance of household expenditure indicators, but only a very small proportion of the variance of child's time spent studying and the quality of the relationship between the child and the parents.

\footnotetext{
8 'If I try hard, I can improve my situation in life'; 'I like to make plans for my future studies and work'; 'If I study hard at school, I will be rewarded by a better job in the future'; 'I have no choice about the work I do, I must do this sort of work' [recoded to positive]; and, 'Other people in my family make all the decisions about how I spend my time' [recoded to positive].

${ }^{9}$ The item 'Other people in my family make all the decisions about how I spend my time' [recoded to positive] was found to be negatively correlated with the other items of the scale in each of the four country samples. Thus, the item was excluded from the analysis. From the remaining items, 'I have no choice about the work I do, I must do this sort of work' [recoded to positive] is also negatively associated with the rest of items in two countries (India and Peru). For comparability purposes, the item was excluded in all the countries.

${ }^{10}$ In the case of Vietnam, expenditure on clothes and education had to be consolidated into one variable to achieve convergence in the estimation.
} 


\section{4.a. Further identification issues}

It is assumed that skills are correctly measured by the above procedure. However, parental investments could still be correlated with child and household unobservable characteristics that are also relevant for skill accumulation (such as the child's innate health and the parent's ability to raise healthy, well-educated children), thus generating omitted variable bias in the estimation. For similar reasons, the earliest measure of height that enters the model (at age 1) is also likely to be endogenous. The inclusion of maternal education in the model controls for parental ability to raise a child. In addition, the area of residence and country-specific geographical location dummies control for geographical differences in the provision of public goods - including the availability and quality of early childhood development programmes and of pre-school facilities. Yet this alone might not be enough.

To deal with the endogeneity of early height and parental investments, a set of household economic shocks are used as instrumental variables. Specifically, shocks that took place between the pregnancy period and age 1 act as instruments for $H_{1 y}$; shocks occurred between age 1 and 5 years act as instruments for $I_{5 y}$ and $I_{5 y}^{H}$ and, similarly, shocks that occurred when the child was aged between 5 and 8 years act as instruments for $I_{8 y}$ and $I_{8 y}^{H}$. In each country, shocks were chosen only when at least 5 percent of the sample was affected by them. At least three shocks were selected per country and per period. Shocks selected included natural disasters (droughts, frosts), crop failure, death of livestock, changes in food availability, changes in input and output prices, death and illness of household members, and job loss, among others. A full list of the shocks used as instruments is presented in Table 3. These events can reasonably be considered to be out of the family's control. Furthermore, the inclusion of area of residence and geographical location dummies alleviates concerns that these shocks are more likely in certain type of locations. For instance, among the Peru sample frosts, crop failure and the death of livestock are more likely to occur in rural areas in the highlands. The use of instrumental variables implies the estimation of the following equation for $H_{1 y}$,

$$
H_{1 y}=\pi_{51}+I V_{1 y} \Pi_{5}+X \Theta_{5}+\pi_{51} \text { AgeMonths }_{1 y}+\eta_{5}
$$

where $I V_{1 y}$ is a vector that includes all the instrumental variables for $H_{1 y}$ reported in Table 3. In this equation I also control for the age of the child in months (AgeMonths ${ }_{1 y}$ ) at the time $H_{1 y}$ was measured (between 6 and 18 months). Similarly, equations are devised for parental investments at age $5\left(I_{5 y}\right.$ and $\left.I_{5 y}^{H}\right)$ and at age 8 (for $I_{8 y}$ and $I_{8 y}^{H}$ ) as follows,

$$
\begin{gathered}
I_{5 y}=\pi_{41}+I V_{5 y} \Pi_{4}+X \Theta_{4}+\eta_{4} \\
I_{5 y}^{H}=\pi_{31}+I V_{5 y} \Pi_{3}+X \Theta_{3}+\eta_{3} \\
I_{8 y}=\pi_{21}+I V_{8 y} \Pi_{2}+X \Theta_{2}+\eta_{2} \\
I_{8 y}^{H}=\pi_{11}+I V_{8 y} \Pi_{1}+X \Theta_{1}+\eta_{1}
\end{gathered}
$$


The model represented in Equations 1 to 10 is estimated by maximum likelihood separately for each country ${ }^{11}$. Joint normality of all observed and estimated factors is assumed conditional on area of residence, geographical location, year of birth and mother's years of education. In addition, errors are assumed to be correlated in Equations 1 to 3 and 4 to 5 . Errors are also clustered within the 20 original clusters in each country sample.

\section{Table 3: Instrumental variables}

\begin{tabular}{ll}
\hline $\begin{array}{l}\text { For height-for-age, age } 1\left(H_{1 y}\right) \\
\text { Household shocks occurring between pregnancy and age } 1\left(I V_{1 y}\right) \\
\text { Common to all countries }\end{array}$ & $\begin{array}{l}\text { Affected by loss of job/source of income/family } \\
\text { enterprises; severe illness or injury of household member; } \\
\text { birth of new household member }\end{array}$ \\
Specific to Ethiopia & $\begin{array}{l}\text { Affected by crop failure; natural disaster; decrease/change } \\
\text { in food availability; death of livestock; death/reduction in } \\
\text { household members; paying for children's education }\end{array}$ \\
Specific to India & $\begin{array}{l}\text { Affected by crop failure; natural disaster; decrease/change } \\
\text { in food availability; death of livestock }\end{array}$ \\
Specific to Vietnam & Affected by crop failure; natural disaster
\end{tabular}

For parental investments, age $5\left(I_{5 y}\right.$ and $\left.I_{5 y}^{H}\right)$

Household shocks occurring between age 1 and $5\left(I V_{5 y}\right)$

Common to all countries

Affected by theft; negative change in input/output prices; loss of job/income source; natural disaster; death of a household member; illness of a household member; food shortage

For parental investments, age $8\left(I_{8 y}\right.$ and $\left.I_{8 y}^{H}\right)$

Household shocks occurring between age 5 and $8\left(I V_{8 y}\right)$

Common to all countries Affected by large increases in input prices; drought; illness of child's mother; illness of other household member

Specific to Ethiopia Affected by frosts or hailstorms; large decreases in output prices; death of livestock; flood or too much rain; pests or diseases affected crops; crop failure; illness of child's father; death of other household member died; erosion; cracks or landslides

Specific to India $\quad$ Affected by death of livestock; flood or too much rain; pests or diseases affected crops; crop failure;

illness of child's father; death of other household member

Specific to Peru Affected by theft/destruction of house or consumer goods; frosts or hailstorms; large decreases in output prices

Specific to Vietnam Affected by theft/destruction of house or consumer goods; large decreases in output prices; death of livestock; flood or too much rain; pests or diseases affected crops; crop failure; pests or diseases; affecting livestock; illness of child's father

\section{$5 \quad$ Results} 11 The SEM command in STATA was used. Typically, between 8 and 20 iterations were required to achieve
convergence. 


\section{5.a Main Results}

The distribution of the estimated latent factors and the correlation matrix are reported in the Supplementary Material (Part B). The correlation matrix (Table B.2) is highly suggestive of strong linkages among all the factors. There is a high level of correlation between cognitive skills, non-cognitive skills, and parental investments in skills across the four countries. Results also suggest the existence of self-productivity for cognitive skills, and of cross-productivity from cognitive skills to non-cognitive skills. In addition, height is found to be highly correlated with cognitive and non- cognitive skills across the four countries. Only in the case of Ethiopia is there no evidence of a correlation between height at age 1 and non-cognitive skills at age 8 .

The main results of the model are reported in Table 4 (Panel A) for each of the country samples and for selected variables (full detail of the results are reported in Table 11 in the Annex). Information about the strength of the instrumental variables is reported in Table B.3 (Supplementary Material, Part $\mathrm{B}^{12}$ ). From here onwards, variables are standardized to have mean zero and variance one. If we look at standard aspects of the technology of skill formation, we see that the results resemble previous findings from the literature (Cunha and Heckman, 2008; Helmers and Patnam, 2011; Coneus et al., 2012). There is a positive relationship between parental investments and cognitive and non-cognitive skills. In addition, results confirm the existence of self-productivity for cognitive skills (which is observed across the four countries), and cross-productivity from cognitive skills to non-cognitive skills, which is observed in all but one country sample (Ethiopia).

Table 4: Model of skill formation: main results

\footnotetext{
${ }^{12}$ Given that the instrumental variables enter the two stages of the model, weak instrumental variable tests cannot be implemented in a standard manner. To check for the strength of the instrumental variables, first I calculate the Kleibergen-Paap F-statistic for Equations 4 and 5 (dependent variable at age 5). In these equations the dependent variables are a direct function of height at age 1 - the first nutritional observation that enters the model - and parental investments at age 5. According to these results (see Table B.3, Part A), the instrumental variables are informative in three of the four country samples. Specifically, using the StockYogo weak identification test critical values, the hypothesis that the selected instrumental variables are weak is rejected at standard levels for India and Ethiopia. The results for Vietnam are mixed (the null hypothesis is rejected in one out of the two equations), while in the case of Peru the hypothesis is not rejected. These results are important because height at age 1 transmits the impact of early nutritional status to the rest of endogenous variables. For Equations 1, 2 and 3 (dependent variables at age 8) the Kleibergen-Paap F-statistic can only be estimated under certain assumptions because these equations belong to the second stage of the structural model. Results assuming that only the variables for parental investments at age 8 are endogenous in these equations are reported in Table B.3 (Part B). The hypothesis that the instrumental variables are weak is rejected for India (in two out of three equations) and Vietnam (in one out of three equations) and is not rejected in Ethiopia and Peru.
} 


\begin{tabular}{|c|c|c|c|c|}
\hline & $\begin{array}{l}\text { Ethiopia } \\
\text { (1) }\end{array}$ & $\begin{array}{c}\text { India } \\
(2)\end{array}$ & $\begin{array}{c}\text { Peru } \\
(3)\end{array}$ & $\begin{array}{l}\text { Vietnam } \\
\text { (4) }\end{array}$ \\
\hline \multicolumn{5}{|l|}{ PANEL A } \\
\hline Cognitive skills, age 5 & $\begin{array}{c}0.128 * * * \\
(0.019)\end{array}$ & $\begin{array}{c}0.220 * * * \\
(0.026)\end{array}$ & $\begin{array}{c}0.264 * * * \\
(0.033)\end{array}$ & $\begin{array}{c}0.206 * * * \\
(0.035)\end{array}$ \\
\hline Height-for-age, age 5 & $\begin{array}{c}0.112 * * * \\
(0.022)\end{array}$ & $\begin{array}{c}0.109 * * * \\
(0.026)\end{array}$ & $\begin{array}{c}0.102 * * * \\
(0.020)\end{array}$ & $\begin{array}{c}0.105^{* * * *} \\
(0.024)\end{array}$ \\
\hline Parental investments, age 8 & $\begin{array}{l}0.252 * * * \\
(0.024)\end{array}$ & $\begin{array}{l}0.117 * * * \\
(0.037)\end{array}$ & $\begin{array}{l}0.178 * * * \\
(0.026)\end{array}$ & $\begin{array}{c}0.158 * * * \\
(0.042)\end{array}$ \\
\hline \multicolumn{5}{|c|}{ Dependent variable: non-cognitive skills, age 8} \\
\hline Cognitive skills, age 5 & $\begin{array}{l}-0.031 \\
(0.035)\end{array}$ & $\begin{array}{c}0.089 * * * \\
(0.028)\end{array}$ & $\begin{array}{c}0.109 * * * \\
(0.029)\end{array}$ & $\begin{array}{c}0.138 * * * \\
(0.034)\end{array}$ \\
\hline Height-for-age, age 5 & $\begin{array}{l}0.033 \\
\quad(0.032)\end{array}$ & $\begin{array}{c}0.039 * \\
(0.020)\end{array}$ & $\begin{array}{l}0.032 \\
\quad(0.025)\end{array}$ & $\begin{array}{c}0.006 \\
(0.020)\end{array}$ \\
\hline Parental investments, age 8 & $\begin{array}{l}0.110 * * \\
(0.052)\end{array}$ & $\begin{array}{c}0.177 * * * \\
(0.037)\end{array}$ & $\begin{array}{c}0.076 * * * \\
(0.022)\end{array}$ & $\begin{array}{c}0.143 * * * \\
(0.046)\end{array}$ \\
\hline \multicolumn{5}{|c|}{ Dependent variable: cognitive skills, age 5} \\
\hline Height-for-age, age 1 & $\begin{array}{c}0.073 * * * \\
(0.022)\end{array}$ & $\begin{array}{c}0.150 * * * \\
(0.023)\end{array}$ & $\begin{array}{c}0.091 * * * \\
(0.025)\end{array}$ & $\begin{array}{c}0.101 * * * \\
(0.028)\end{array}$ \\
\hline Parental investments, age 5 & $\begin{array}{c}0.145 * * * \\
(0.030)\end{array}$ & $\begin{array}{l}0.098 * * * \\
(0.031)\end{array}$ & $\begin{array}{l}0.242 * * * \\
(0.018)\end{array}$ & $\begin{array}{c}0.093 \\
(0.058)\end{array}$ \\
\hline \multicolumn{5}{|c|}{ Dependent variable: height-for-age, age 8} \\
\hline Cognitive skills, age 5 & $\begin{array}{l}0.057 * \\
(0.033)\end{array}$ & $\begin{array}{c}-0.050 * * \\
(0.024)\end{array}$ & $\begin{array}{c}0.039 * * \\
(0.019)\end{array}$ & $\begin{array}{c}0.048 * * \\
(0.022)\end{array}$ \\
\hline Height-for-age, age 5 & $\begin{array}{c}0.644 * * * \\
(0.036)\end{array}$ & $\begin{array}{c}0.725 * * * \\
(0.026)\end{array}$ & $\begin{array}{c}0.754 * * * \\
(0.019)\end{array}$ & $\begin{array}{c}0.808 * * * \\
(0.047)\end{array}$ \\
\hline Parental investments, age 8 & $\begin{array}{c}0.071 * * * \\
(0.025)\end{array}$ & $\begin{array}{l}0.063 * * * \\
(0.023)\end{array}$ & $\begin{array}{l}0.044 * * * \\
(0.015)\end{array}$ & $\begin{array}{l}0.033 * \\
(0.017)\end{array}$ \\
\hline \multicolumn{5}{|c|}{ Dependent variable: height-for-age, age 5} \\
\hline Height-for-age, age 1 & $\begin{array}{c}0.393^{* * *} \\
(0.062)\end{array}$ & $\begin{array}{c}0.525 * * * \\
(0.040)\end{array}$ & $\begin{array}{c}0.510 * * * \\
(0.028)\end{array}$ & $\begin{array}{c}0.600 * * * \\
(0.025)\end{array}$ \\
\hline Parental investments, age 5 & $\begin{array}{c}0.027 \\
(0.032)\end{array}$ & $\begin{array}{c}0.115 * * * \\
(0.035)\end{array}$ & $\begin{array}{c}0.076 * * * \\
(0.026)\end{array}$ & $\begin{array}{c}0.107 * * * \\
(0.027)\end{array}$ \\
\hline \multicolumn{5}{|c|}{ PANEL B: total effects of height-for-age at age 1} \\
\hline On cognitive skills, age 8 & $\begin{array}{l}0.054 * * * \\
(0.009)\end{array}$ & $\begin{array}{l}0.090 * * * \\
(0.008)\end{array}$ & $\begin{array}{l}0.076^{* * *} * \\
(0.009)\end{array}$ & $\begin{array}{c}0.084 * * * \\
(0.006)\end{array}$ \\
\hline \multirow{2}{*}{$\begin{array}{l}\text { On non-cognitive skills, age } \\
8\end{array}$} & $0.011 * * *$ & $0.034 * * *$ & $0.026 * * *$ & $0.017 * * *$ \\
\hline & $(0.002)$ & $(0.003)$ & $(0.003)$ & $(0.004)$ \\
\hline $\mathrm{N}$ & 1440 & 1676 & 1661 & 1407 \\
\hline
\end{tabular}

Notes: Standardized coefficients reported. Clustered standard errors reported in parentheses.* indicates significance at $10 \%$; ** at 5\%; *** at 1\%. All instrumental variables reported in Table 3 are used. Estimations also control for mother's years of education, year of birth fixed effects, country-specific geographical dummies, and whether the child was born in a rural area. In Panel B, standard errors obtained by the Delta method are reported. 
Moving on to the role of parental investments, their impact on cognitive skills is larger than the impact of parental investments in non-cognitive skills for Ethiopia and Peru, but the opposite is the case for India (in all cases differences are statistically significant). In the case of Vietnam, the difference is not statistically significant. In addition, regarding the role of some of the control variables in the formation of skills (Table 11 in the Annex), results show that cognitive skills at age 8 tend to be more sensitive than non-cognitive skills at the same age to differences in maternal education and area of residence at birth (differences are statistically significant for maternal education in Ethiopia, Peru and Vietnam, and for area of residence in Ethiopia, India and Peru).

Moving on to the role of nutrition, results confirm the importance of early nutritional status as an input in the formation of skills. Height at age 1 is found to have a direct effect on cognitive skills at age 5 that ranges between 7 percent and 15 percent of a standard deviation depending on the country sample. These estimates are aligned with previous studies that have looked at the same relationship in other countries (Glewwe et al., 2001; Alderman et al., 2006). In addition, height at age 5 is also found to have a direct effect on cognitive skills at age 8 . In this case, the effect is very similar across countries, around 10 percent of a standard deviation. This finding is important as it suggests improvements in height can lead to cognitive gains, even if they take place after the first few years of life. This is consistent with evidence from studies that have found evidence of catch-up growth and catch-up cognition beyond the first 1,000 days of life (Crookston et al., 2010, 2013).

On the other hand, I find little evidence that height at age 5 has a direct effect on noncognitive skills at age 8. Only for India is such an effect detected. Moreover, the coefficient of height at age 5 on cognitive skills at age 8 is larger than the one on noncognitive skills at age 8 in the four country samples (differences are statistically significant). In addition, as explained in Section 3, the model is not equipped to observe the potential direct effect of height at age 1 on non-cognitive skills at age 5 . Notwithstanding this limitation, within the proposed structure height at age 1 can also affect non-cognitive skills through an indirect channel: the cross-productivity from cognitive to non-cognitive skills. More generally, the total effect of height at age 1 on non-cognitive skills at age 8 is given by $\beta_{23} \beta_{53}+\beta_{24} \beta_{43}$. These results are reported in Table 4 (Panel $\mathrm{B})^{13}$. I find that an increase of one standard deviation in height at the age of 1 increases non-cognitive skills at age 8 by 1.1 percent in Ethiopia, 3.4 percent in India, 2.6 percent in Peru and 1.7 percent in Vietnam. T he corresponding total effect of height at age 1 on cognitive skills at age 8 (given by $\beta_{13} \beta_{53}+\beta_{14} \beta_{13}$ ) are as follows: 5.4 percent in Ethiopia, 9.0 percent in India, 7.6 percent in Peru and 8.4 percent in Vietnam. In all cases, results are statistically significant.

It is relevant to establish to what extent these results are informative of the impact of early nutritional status on skill formation. This is because not all the variation observed across the distribution of height-for-age of young children can be interpreted necessarily as being the result of differences in nutritional status. A good indicator of chronic malnutrition is stunting (whether the child has a height-for-age that is two standard deviations below the norm for a healthy child). Stunting is thought to be caused by poor maternal nutrition, poor feeding practices and poor food quality as well as frequent infections, which can slow down growth. In Table 5, alternative results are

\footnotetext{
${ }^{13}$ Standard errors of the total effects are estimated using the Delta method.
} 
reported, in which height-for-age is replaced by stunting, leaving the rest of the model un-changed. Results are qualitatively similar to those obtained before. The only important caveat is that in the case of Ethiopia, the effect on non-cognitive skills has the reverse sign. Thus, caution is needed in interpreting the results for this country.

Table 5: Total effects of stunting at age 1 on skills at age 8

\begin{tabular}{|c|c|c|c|c|}
\hline & $\begin{array}{l}\text { Ethiopia } \\
\text { (1) }\end{array}$ & $\begin{array}{l}\text { India } \\
(2)\end{array}$ & $\begin{array}{l}\text { Peru } \\
(3)\end{array}$ & $\begin{array}{l}\text { Vietnam } \\
\text { (4) }\end{array}$ \\
\hline On cognitive skills, age 8 & $\begin{array}{c}-0.024 * * * \\
(0.005)\end{array}$ & $\begin{array}{c}-0.042 * * * \\
(0.007)\end{array}$ & $\begin{array}{c}-0.038 * * * \\
(0.008)\end{array}$ & $\begin{array}{l}-0.040 * * * \\
(0.004)\end{array}$ \\
\hline On non-cognitive skills, age 8 & $\begin{array}{c}0.005 * * * \\
(0.001)\end{array}$ & $\begin{array}{c}-0.016 * * * \\
(0.003)\end{array}$ & $\begin{array}{c}-0.012 * * * \\
(0.003)\end{array}$ & $\begin{array}{c}-0.010 * * * \\
(0.003)\end{array}$ \\
\hline $\mathrm{N}$ & 1440 & 1676 & 1661 & 1407 \\
\hline
\end{tabular}

As a benchmark for these estimates, alternative results using only observed indicators of skills and parental investments are reported. In particular, cognitive skills at ages 8 and 5 are replaced by the maths test and the CDA test (respectively), which capture most of the variation in cognitive skills; parental investments in skills and nutrition are replaced by household consumption in non- food and food items, respectively (expressed in logs, in per capita terms); and, non-cognitive skills are replaced by the self-efficacy indicator (Table 6) or, alternatively, by the self-esteem indicator (Table 7). In both cases, results are similar to those previously shown, although point estimates are smaller.

In addition, alternative results are reported, in which the only difference with respect to the original model is that no instrumental variables are used (see Table A.1 in the Supplementary Material, Part A). Point estimates do not vary in any meaningful way when instrumental variables are excluded, but standard errors are larger, with the total effects of height at age 1 on non-cognitive skills losing statistical significance for Ethiopia and Vietnam. Overall, the combined use of latent factors and instrumental variables seems to bring some clarity to the analysis of the skill formation process by dealing mainly with measurement error.

Table 6: Model of skill formation: alternative results using observable indicators of skills (maths test, CDA and self-efficacy) and parental investments (household expenditure) 


\begin{tabular}{|c|c|c|c|c|}
\hline & $\begin{array}{c}\text { Ethiopia } \\
\text { (1) }\end{array}$ & $\begin{array}{l}\text { India } \\
(2)\end{array}$ & $\begin{array}{l}\text { Peru } \\
(3)\end{array}$ & $\begin{array}{l}\text { Vietnam } \\
\text { (4) }\end{array}$ \\
\hline \multicolumn{5}{|c|}{ PANEL A } \\
\hline \multicolumn{5}{|c|}{ Dependent variable: maths test, age 8} \\
\hline CDA, age 5 & $\begin{array}{c}0.126 * * * \\
(0.022)\end{array}$ & $\begin{array}{c}0.221 * * * \\
(0.023)\end{array}$ & $\begin{array}{c}0.174 * * * \\
(0.028)\end{array}$ & $\begin{array}{c}0.116^{* * *} \\
(0.036)\end{array}$ \\
\hline Height-for-age, age 5 & $\begin{array}{c}0.119 * * * \\
(0.024)\end{array}$ & $\begin{array}{c}0.124 * * * \\
(0.027)\end{array}$ & $\begin{array}{c}0.104 * * * \\
(0.021)\end{array}$ & $\begin{array}{c}0.092 * * * \\
(0.022)\end{array}$ \\
\hline Non-food consumption, age 8 & $\begin{array}{c}0.156^{* * *} \\
(0.028)\end{array}$ & $\begin{array}{c}0.090 * * * \\
(0.033)\end{array}$ & $\begin{array}{c}0.174 * * * \\
(0.028)\end{array}$ & $\begin{array}{c}0.155^{* * *} * \\
(0.03)\end{array}$ \\
\hline \multicolumn{5}{|c|}{ Dependent variable: self-efficacy score, age 8} \\
\hline CDA, age 5 & $\begin{array}{c}0.015 \\
(0.034)\end{array}$ & $\begin{array}{c}0.071 * * * \\
(0.025)\end{array}$ & $\begin{array}{c}0.087 * * * \\
(0.03)\end{array}$ & $\begin{array}{c}0.111 * * * \\
(0.035)\end{array}$ \\
\hline Height-for-age, age 5 & $\begin{array}{l}0.008 \\
(0.03)\end{array}$ & $\begin{array}{c}0.043 * * * \\
(0.016)\end{array}$ & $\begin{array}{c}0.056^{* *} \\
(0.028)\end{array}$ & $\begin{array}{c}0.014 \\
(0.028)\end{array}$ \\
\hline Non-food consumption, age 8 & $\begin{array}{c}0.038 \\
(0.048)\end{array}$ & $\begin{array}{c}0.058 * * \\
(0.026)\end{array}$ & $\begin{array}{c}0.002 \\
(0.037)\end{array}$ & $\begin{array}{c}0.110 * * * \\
(0.025)\end{array}$ \\
\hline \multicolumn{5}{|c|}{ Dependent variable: CDA, age 5} \\
\hline Height-for-age, age 1 & $\begin{array}{c}0.081 * * * \\
(0.024)\end{array}$ & $\begin{array}{c}0.126 * * * \\
(0.021)\end{array}$ & $\begin{array}{c}0.021 \\
(0.027)\end{array}$ & $\begin{array}{c}0.029 \\
(0.029)\end{array}$ \\
\hline Non-food consumption, age 5 & $\begin{array}{c}0.104 * * * \\
(0.039)\end{array}$ & $\begin{array}{c}0.124 * * * \\
(0.038)\end{array}$ & $\begin{array}{c}0.231 * * * \\
(0.028)\end{array}$ & $\begin{array}{c}0.180 * * * \\
(0.057)\end{array}$ \\
\hline \multicolumn{5}{|c|}{ Dependent variable: height-for-age, age 8} \\
\hline CDA, age 5 & $\begin{array}{c}0.035 \\
(0.025)\end{array}$ & $\begin{array}{l}-0.021 \\
(0.02)\end{array}$ & $\begin{array}{c}0.022 \\
(0.017)\end{array}$ & $\begin{array}{c}0.025 \\
(0.023)\end{array}$ \\
\hline Height-for-age, age 5 & $\begin{array}{c}0.647 * * * \\
(0.036)\end{array}$ & $\begin{array}{c}0.721 * * * \\
(0.026)\end{array}$ & $\begin{array}{c}0.758 * * * \\
(0.019)\end{array}$ & $\begin{array}{c}0.811^{* * * *} \\
(0.047)\end{array}$ \\
\hline Non-food consumption, age 8 & $\begin{array}{c}0.068 * * * \\
(0.02)\end{array}$ & $\begin{array}{c}0.053 * * \\
(0.022)\end{array}$ & $\begin{array}{c}0.035^{* *} \\
(0.015)\end{array}$ & $\begin{array}{c}0.043 * * * \\
(0.013)\end{array}$ \\
\hline \multicolumn{5}{|c|}{ Dependent variable: height-for-age, age 5} \\
\hline Height-for-age, age 1 & $\begin{array}{c}0.393 * * * \\
(0.061)\end{array}$ & $\begin{array}{c}0.525 * * * \\
(0.041)\end{array}$ & $\begin{array}{c}0.512 * * * \\
(0.028)\end{array}$ & $\begin{array}{c}0.600 * * * \\
(0.025)\end{array}$ \\
\hline Food consumption, age 5 & $\begin{array}{c}0.044 \\
(0.034) \\
\end{array}$ & $\begin{array}{c}0.094 * * * \\
(0.026)\end{array}$ & $\begin{array}{c}0.080 * * * \\
(0.026)\end{array}$ & $\begin{array}{c}0.115^{* * *} * \\
(0.022)\end{array}$ \\
\hline \multicolumn{5}{|c|}{ PANEL B: total effects of height-for-age at age 1} \\
\hline On maths test, age 8 & $\begin{array}{c}0.057 * * * \\
(0.009)\end{array}$ & $\begin{array}{c}0.093 * * * \\
(0.008)\end{array}$ & $\begin{array}{c}0.057 * * * \\
(0.006)\end{array}$ & $\begin{array}{c}0.058 * * * \\
(0.005)\end{array}$ \\
\hline On self-efficacy score, age 8 & $\begin{array}{c}0.004 * * * \\
(0.001)\end{array}$ & $\begin{array}{c}0.032 * * * \\
(0.003)\end{array}$ & $\begin{array}{c}0.031 * * * \\
(0.003)\end{array}$ & $\begin{array}{c}0.012 * * * \\
(0.003)\end{array}$ \\
\hline $\mathrm{N}$ & 1440 & 1676 & 1661 & 1407 \\
\hline $\begin{array}{l}\text { Notes: Standardized coefficients re } \\
\text { significance at } 10 \% ; * * \text { at } 5 \% ; \\
\text { Estimations also control for mothe } \\
\text { geographical dummies, and whether } \\
\text { by the Delta method are reported. }\end{array}$ & $\begin{array}{l}\text { All instrume } \\
\text { f education, } \\
\text { as born in a r }\end{array}$ & $\begin{array}{l}\text { errors report } \\
\text { variables re } \\
\text { r of birth fix }\end{array}$ & $\begin{array}{l}\text { in parenthes } \\
\text { rted in Tabl } \\
\text { d effects, co }\end{array}$ & $\begin{array}{l}* \text { indicates } \\
3 \text { are used. } \\
\text { try-specific } \\
\text { rs obtained }\end{array}$ \\
\hline
\end{tabular}

Table 7: Model of skill formation: alternative results using observable indicators of skills (maths test, CDA and self-esteem) and parental investments (household expenditure) 


\begin{tabular}{|c|c|c|c|c|}
\hline & $\begin{array}{l}\text { Ethiopia } \\
\text { (1) }\end{array}$ & $\begin{array}{l}\text { India } \\
(2)\end{array}$ & $\begin{array}{l}\text { Peru } \\
\text { (3) }\end{array}$ & $\begin{array}{l}\text { Vietnam } \\
\text { (4) }\end{array}$ \\
\hline \multicolumn{5}{|c|}{ PANEL A } \\
\hline \multicolumn{5}{|c|}{ Dependent variable: maths test, age 8} \\
\hline CDA, age 5 & $\begin{array}{c}0.126 * * * \\
(0.022)\end{array}$ & $\begin{array}{c}0.221 * * * \\
(0.023)\end{array}$ & $\begin{array}{c}0.174 * * * \\
(0.028)\end{array}$ & $\begin{array}{c}0.116^{* * * *} \\
(0.036)\end{array}$ \\
\hline Height-for-age, age 5 & $\begin{array}{c}0.119 * * * \\
(0.024)\end{array}$ & $\begin{array}{c}0.124 * * * \\
(0.027)\end{array}$ & $\begin{array}{c}0.104 * * * \\
(0.021)\end{array}$ & $\begin{array}{c}0.092 * * * * \\
(0.022)\end{array}$ \\
\hline Non-food consumption, age 8 & $\begin{array}{c}0.156^{* * * *} \\
(0.028)\end{array}$ & $\begin{array}{c}0.090 * * * \\
(0.033)\end{array}$ & $\begin{array}{c}0.174 * * * \\
(0.028)\end{array}$ & $\begin{array}{c}0.155^{* * * *} \\
(0.03)\end{array}$ \\
\hline \multicolumn{5}{|c|}{ Dependent variable: self-esteem score, age 8} \\
\hline CDA, age 5 & $\begin{array}{l}-0.049 * \\
(0.028)\end{array}$ & $\begin{array}{c}0.054 * * \\
(0.022)\end{array}$ & $\begin{array}{l}0.052 * \\
(0.030)\end{array}$ & $\begin{array}{c}0.040 \\
(0.032)\end{array}$ \\
\hline Height-for-age, age 5 & $\begin{array}{c}0.052 \\
(0.038)\end{array}$ & $\begin{array}{c}0.046 \\
(0.031)\end{array}$ & $\begin{array}{c}0.014 \\
(0.021)\end{array}$ & $\begin{array}{c}-0.003 \\
(0.024)\end{array}$ \\
\hline Non-food consumption, age 8 & $\begin{array}{c}0.143 * * * \\
(0.035)\end{array}$ & $\begin{array}{l}0.123 * * \\
(0.035)\end{array}$ & $\begin{array}{c}0.102 * * * \\
(0.029)\end{array}$ & $\begin{array}{c}0.120 * * * * \\
(0.038)\end{array}$ \\
\hline \multicolumn{5}{|c|}{ Dependent variable: CDA, age 5} \\
\hline Height-for-age, age 1 & $\begin{array}{c}0.081 * * * \\
(0.024)\end{array}$ & $\begin{array}{c}0.126 * * * \\
(0.021)\end{array}$ & $\begin{array}{c}0.021 \\
(0.027)\end{array}$ & $\begin{array}{c}0.029 \\
(0.029)\end{array}$ \\
\hline Non-food consumption, age 5 & $\begin{array}{c}0.104 * * * \\
(0.039)\end{array}$ & $\begin{array}{c}0.124 * * * \\
(0.038)\end{array}$ & $\begin{array}{c}0.231 * * * \\
(0.028)\end{array}$ & $\begin{array}{c}0.180 * * * * \\
(0.057)\end{array}$ \\
\hline \multicolumn{5}{|c|}{ Dependent variable: height-for-age, age 8} \\
\hline CDA, age 5 & $\begin{array}{c}0.035 \\
(0.025)\end{array}$ & $\begin{array}{l}-0.021 \\
(0.02)\end{array}$ & $\begin{array}{c}0.022 \\
(0.017)\end{array}$ & $\begin{array}{c}0.025 \\
(0.023)\end{array}$ \\
\hline Height-for-age, age 5 & $\begin{array}{c}0.647 * * * \\
(0.036)\end{array}$ & $\begin{array}{c}0.721 * * * \\
(0.026)\end{array}$ & $\begin{array}{c}0.758 * * * \\
(0.019)\end{array}$ & $\begin{array}{c}0.811^{* * * *} \\
(0.047)\end{array}$ \\
\hline Non-food consumption, age 8 & $\begin{array}{c}0.068 * * * \\
(0.02)\end{array}$ & $\begin{array}{c}0.053^{* *} \\
(0.022)\end{array}$ & $\begin{array}{c}0.035^{* *} \\
(0.015)\end{array}$ & $\begin{array}{c}0.043^{* * * *} \\
(0.013)\end{array}$ \\
\hline \multicolumn{5}{|c|}{ Dependent variable: height-for-age, age 5} \\
\hline Height-for-age, age 1 & $\begin{array}{c}0.393 * * * \\
(0.061)\end{array}$ & $\begin{array}{c}0.525 * * * \\
(0.041)\end{array}$ & $\begin{array}{c}0.512 * * * \\
(0.028)\end{array}$ & $\begin{array}{c}0.600^{* * * *} \\
(0.025)\end{array}$ \\
\hline Food consumption, age 5 & $\begin{array}{c}0.044 \\
(0.034) \\
\end{array}$ & $\begin{array}{c}0.094 * * * \\
(0.026) \\
\end{array}$ & $\begin{array}{c}0.080 * * * \\
(0.026)\end{array}$ & $\begin{array}{c}0.115^{* * * *} \\
(0.022) \\
\end{array}$ \\
\hline \multicolumn{5}{|c|}{ PANEL B: total effects of height-for-age at age 1} \\
\hline On maths test, age 8 & $\begin{array}{c}0.057 * * * \\
(0.009)\end{array}$ & $\begin{array}{c}0.093 * * * \\
(0.008)\end{array}$ & $\begin{array}{c}0.057 * * * \\
(0.006)\end{array}$ & $\begin{array}{c}0.058 * * * \\
(0.005)\end{array}$ \\
\hline On self-esteem score, age 8 & $\begin{array}{c}0.016^{* * * *} \\
(0.003)\end{array}$ & $\begin{array}{c}0.031 * * * \\
(0.003)\end{array}$ & $\begin{array}{c}0.008 * * * \\
(0.002)\end{array}$ & $\begin{array}{c}0.012 * * * * \\
(0.003)\end{array}$ \\
\hline $\mathrm{N}$ & 1440 & 1676 & 1661 & 1407 \\
\hline $\begin{array}{l}\text { Notes: Standardized coefficients re } \\
\text { significance at } 10 \% ; * * \text { at } 5 \% \text {; } \\
\text { Estimations also control for mothe } \\
\text { geographical dummies, and whether } \\
\text { by the Delta method are reported. }\end{array}$ & $\begin{array}{l}\text { ustered stanc } \\
\text { All instrum } \\
\text { of education } \\
\text { was born in a }\end{array}$ & $\begin{array}{l}\text { errors repor } \\
l \text { variables } r \\
\text { ar of birth } f\end{array}$ & $\begin{array}{l}1 \text { in parenthe } \\
\text { orted in Tab }\end{array}$ & $\begin{array}{l}* \text { indicates } \\
3 \text { are used } \\
\text { try-specific } \\
\text { ors obtained }\end{array}$ \\
\hline
\end{tabular}

\section{5.b Robustness checks}


One potential concern is that household poverty, a well-known determinant of nutritional and cognitive outcomes, and which also has been shown to shape noncognitive skills (Dercon and Krishnan, 2009), might be driving the results. To deal with this concern, the model is re-estimated incorporating household wealth as a control variable when the child was 1, 5 and 8 years old. Specifically, household wealth when the child was 1 year old is introduced as a determinant of height at age 1, household wealth when the child was 5 years old as a determinant of height and skills at age 5, and analogously for outcomes at age 8 with household wealth when the child was

8 year old as a control. Household wealth is proxied by the wealth index, a composite measure that comprises information related to household access to services (electricity, drinking water, toilet facilities), housing quality (main material used for floor, wall and roof) and durable goods (including TV, radio, fridge, and computer, among others). Some of the dimensions contained in the wealth index can be classified as investments in the child in their own right, which complicates the interpretation of the coefficients if household wealth and parental investments are introduced simultaneously (in fact, it is for this reason that the wealth index is not included in the original model). Results are reported in Table A.2 (Supplementary Material, Part A). It is reassuring that previous conclusions remain unchanged. The total effects of height on skills are only slightly smaller.

A final question is whether the estimation can be improved using additional information about nutritional status. The key nutrition-related information in the Young Lives survey comes from the anthropometric data. Height and weight (expressed in WHO zscores) are both informative of nutritional status. Although they tend to correlate ${ }^{14}$, conceptually they measure different things: height-for-age is informative of a child's history of nutrition, whereas weight-for-age is associated with short-term food intake. As a robustness check, a latent factor for nutrition is calculated using height-for-age and weight-for-age as observed indicators, and the model is re-estimated replacing height by this factor - see Table A.3 (Supplementary Material, Part A). Results are very similar, with the coefficients linking nutrition and skills being slightly larger in this case.

\section{5.c Implications of the results}

Results show that improvements in height during infancy are associated with improvements in cognitive and non-cognitive skills at the age of 8 , when children have just started school. These findings help to build a bridge between the early childhood development literature and the skill formation literature. At the same time, it is important to highlight that the effects on non-cognitive skills are small: about a third of the analogous effects on cognitive skills in India and Peru, and about a fifth in the case of Ethiopia and Vietnam. The finding that non-cognitive skills are less sensitive to changes in early nutrition than cognitive skills might be related to several factors. The literature suggests that sensitive periods for non-cognitive skills occur at later ages than sensitive periods for cognitive skills (Borghans et al., 2008; Cunha and Heckman, 2008). Following this notion it is possible that non-cognitive skills are less malleable

\footnotetext{
${ }^{14}$ The correlation between height-for-age and weight-for-age at age 8 in Ethiopia, India, Peru and Vietnam is 69 percent, 68 percent, 66 percent and 74 percent, respectively.
} 
than cognitive skills at age 8. In support of this hypothesis, let us note that between the ages of 1 and 8 non-cognitive skills tend to be less sensitive to variations in maternal education and area of residence at birth (and, in the cases of Peru and Ethiopia, to changes in parental investments) than cognitive skills at age 8. On the other hand, it is possible that investments in early nutrition are less important for the development of non-cognitive skills than for the development of cognitive skills. Noncognitive skills might indeed be equally sensitive or even more sensitive than cognitive skills to other forms of investments not directly modelled here, such as the quality of the interaction between the mother and the child or the quality of the pre-school education the child had. Finally, the result might be partially driven by one of the limitations of the model, namely that non-cognitive skills at the age of 5 are not observed. This might be attenuating the total effect of height at age 1 on non-cognitive skills at age 8 .

To offer more perspective on the implications of the results for skill formation, in Table 8 (Panel A) I report selected total effects that derive from the coefficients of the main model. One thing to bear in mind when interpreting these findings is that the analysis lacks information on costs, which means that no claim can be made about costeffectiveness. I find that a one standard deviation increase in parental investments at age 8 has larger effects on skills than an analogous improvement in height at age 1. Part of the reason behind this result is that, in using the coefficients from the estimated model, it is assumed that any increase in earlier investments is short-lived. However, let us suppose that the increase in height at the age of 1 were to be persistent (i.e., that the coefficient $\beta 53$ is close to 1). In that case, a one standard deviation increase in height at the age of 1 has an effect on cognitive skills that is closer to an analogous increase in contemporaneous parental investments (see Panel B). But even in this case, the effect of height on non-cognitive skills is many time weaker than the effect of contemporaneous parental investments on the same outcome. Finally, results also show that simultaneous increases in earlier and contemporaneous parental investments should typically lead to even better outcomes in terms of skill acquisition. This is certainly the case for India, Peru and, to a certain extent, Vietnam (for this country sample the coefficients are not always statistically significant; however point estimates are similar to those obtained for India and Peru). In the case of Ethiopia, one caveat is that one coefficient related to non-cognitive skills has the unexpected sign (the effect of parental investments at age 5 on non-cognitive skills is negative).

Finally, we reflect on the potential impact of policies designed to improve early nutrition in order to boost skill formation. The main model does not offer insights on this front. In order to better understand the implications of the analysis, the main model is redefined so that it includes the determinants of height at age 1. In particular, I consider things that can be implemented via social policy (e.g., conditional cash transfer programmes, infrastructure programmes, health services for pregnant women), which are observed in the data and which were not considered in the main model because of its endogenous nature. The following individual and household characteristics are considered: food consumption (only observed for Peru); access to drinking water; access to sewage system; and, number of antenatal visits when the mother was expecting the child. In Table 12, I report how these factors affect skills at age 8. I find that improvements in certain areas lead to improvements in cognitive skills but not in noncognitive skills - or rather that the effects on non-cognitive skills are too small to be detected. Moreover, even the effects on cognitive skills are small. Moving a household 
from the first to the second quintile of food consumption in Peru (which can be achieved with a conditional cash transfer programme) when the child is 1 year old, increases cognitive skills by 0.4 percent in Peru. Installing a flush toilet when the child is 1 year old (which reduces the risk of diarrhoeal diseases) increases cognitive skills by 0.7 percent in India, Peru and Vietnam. Increasing the number of antenatal visits also improves cognitive skills. But none of these improvements affect non-cognitive skills (or if they do the effects are too small to be detected).

Table 8: Total effects of selected variables

\begin{tabular}{|c|c|c|c|c|}
\hline & $\begin{array}{c}\text { Ethiopia } \\
\text { (1) }\end{array}$ & $\begin{array}{l}\text { India } \\
(2)\end{array}$ & $\begin{array}{l}\text { Peru } \\
(3)\end{array}$ & $\begin{array}{c}\text { Vietnam } \\
\text { (4) }\end{array}$ \\
\hline \multicolumn{5}{|l|}{ PANEL A } \\
\hline Height-for-age, age 1 & $\begin{array}{c}0.054 * * * \\
(0.009)\end{array}$ & $\begin{array}{c}0.09 * * * \\
(0.008)\end{array}$ & $\begin{array}{c}0.076^{* * *} * \\
(0.009)\end{array}$ & $\begin{array}{c}0.084 * * * \\
(0.006)\end{array}$ \\
\hline Parental investments in skills, age 5 & $\begin{array}{c}0.019 * * * \\
(0.004)\end{array}$ & $\begin{array}{c}0.021 * * * \\
(0.007)\end{array}$ & $\begin{array}{c}0.064 * * * \\
(0.005)\end{array}$ & $\begin{array}{c}0.019 \\
(0.012)\end{array}$ \\
\hline Parental investments in skills, age 8 & $\begin{array}{c}0.252 * * * \\
(0.024)\end{array}$ & $\begin{array}{c}0.117 * * * \\
(0.037)\end{array}$ & $\begin{array}{c}0.178 * * * \\
(0.026)\end{array}$ & $\begin{array}{c}0.158^{* * *} * \\
(0.042)\end{array}$ \\
\hline Parental investments in nutrition, age 5 & $\begin{array}{c}0.003 \\
(0.004)\end{array}$ & $\begin{array}{c}0.013 * * * \\
(0.004)\end{array}$ & $\begin{array}{c}0.008 * * * \\
(0.003)\end{array}$ & $\begin{array}{c}0.011 * * * \\
(0.003)\end{array}$ \\
\hline Mother's years of education & $\begin{array}{c}0.246 * * * \\
(0.023)\end{array}$ & $\begin{array}{c}0.355 * * * \\
(0.032)\end{array}$ & $\begin{array}{c}0.438 * * * \\
(0.031)\end{array}$ & $\begin{array}{c}0.395 * * * \\
(0.044)\end{array}$ \\
\hline Total effects on non-cognitive skills at & & & & \\
\hline Height-for-age, age 1 & $\begin{array}{c}0.011 * * * \\
(0.002)\end{array}$ & $\begin{array}{c}0.034 * * * \\
(0.003)\end{array}$ & $\begin{array}{c}0.026 * * * \\
(0.003)\end{array}$ & $\begin{array}{c}0.017 * * * * \\
(0.004)\end{array}$ \\
\hline Parental investments in skills, age 5 & $\begin{array}{c}-0.005^{* * *} * \\
(0.001)\end{array}$ & $\begin{array}{c}0.009 * * * \\
(0.003)\end{array}$ & $\begin{array}{c}0.026^{* * * *} \\
(0.002)\end{array}$ & $\begin{array}{c}0.013 \\
(0.008)\end{array}$ \\
\hline Parental investments in skills, age 8 & $\begin{array}{c}0.110 * * \\
(0.052)\end{array}$ & $\begin{array}{c}0.177 * * * \\
(0.037)\end{array}$ & $\begin{array}{c}0.076 * * * \\
(0.022)\end{array}$ & $\begin{array}{c}0.143 * * * \\
(0.046)\end{array}$ \\
\hline Parental investments in nutrition, age 5 & $\begin{array}{c}0.001 \\
(0.001)\end{array}$ & $\begin{array}{c}0.004 * * * \\
(0.001)\end{array}$ & $\begin{array}{c}0.002 * * * \\
(0.001)\end{array}$ & $\begin{array}{c}0.001 \\
(0.000)\end{array}$ \\
\hline Mother's years of education & $\begin{array}{c}0.068 \\
(0.041)\end{array}$ & $\begin{array}{c}0.239 * * * \\
(0.033)\end{array}$ & $\begin{array}{c}0.164 * * * \\
(0.027)\end{array}$ & $\begin{array}{c}0.188^{* * * *} \\
(0.045)\end{array}$ \\
\hline
\end{tabular}

PANEL B

Total effects on cognitive skills at age 8

Height-for-age, age 1 (persistent increase)

0.121

0.142

0.126

0.126

Total effects on non-cognitive skills at age 8

Height-for-age, age 1 (persistent increase)

\begin{tabular}{lllll}
\hline $\mathrm{N}$ & 1440 & 1676 & 1661 & 1407 \\
\hline Notes: Standardized coefficients reported. In Panel A, standard errors (obtained by the Delta method) are reported in
\end{tabular}
parenthesis. * indicates significance at $10 \%, * *$ at $5 \%, * * *$ at $1 \%$.

\section{Conclusions}

It is known that nutritional status has an effect on cognitive skills. I contribute to the literature by testing a model in which early nutrition can have an impact on both cognitive and non-cognitive skills. Although in the absence of experimental variation 
in early height it is not possible to claim causality, my methodology addresses some of the main concerns regarding the endogenous nature of nutritional status, using a number of controls for household wealth and country-specific geographical fixed effects, and also including economic shocks as instrumental variables. My results replicate some of the findings from the skill formation literature, in particular the importance of parental investments for the formation of cognitive and non-cognitive skills, and the existence of self-productivity and cross-productivity.

Looking specifically at the role of early nutrition, I find that improvements in height during the first year of life have an effect on cognitive and non-cognitive skills. The effect on non-cognitive skills is indirect, mediated by cognitive skills. It should be noted that height could still have a direct effect on non-cognitive skills at an early period, though this cannot be captured owing to data limitations. In addition, my results show that improvements in height beyond the early childhood period can also lead to cognitive gains.

The relationships found are similar across countries, which suggests the existence of a similar underlying technology of skill formation. The only caveat relates to the formation of non-cognitive skills in Ethiopia, for which the existence of crossproductivity from cognitive to non-cognitive skills does not hold. However, the process of cognitive skill formation is remarkably similar across the four countries. As for the effects of early height on skills at age 8, the effects on non-cognitive skills can be deemed small. In fact, simulations show that certain policies designed to improve nutrition during the first year of life would have only a modest effect on cognitive skills and no detectable effects on non-cognitive skills. Overall, investing in early nutrition is important, but if the objective is to maximize skills, the best strategy is to simultaneously increase both investments in health and nutrition and investments in skill. 


\section{References}

Albetrsson-Wikland, K., Karlberg, JPE., 1995. Selection of cut-off points in defining shortness.019th International Symposium Growth Hormone and Growth Factors in Endocrinology and Metabolism.

Alderman, H., Hoddinott, J., Kinsey, B., 2006. Long term consequences of early childhood mal- nutrition. Oxford Economic Papers 58 (3) 450-474.

Black, M., Baqui, A., Zaman, K., Persson, L., Arifeen, S., Le, K., McNary, S., Parveen, M., Hamadani, K., Black, R., 2004. Iron and zinc supplementation promote motor development and exploratory behavior among Bangladeshi infants. The American Journal of Clinical Nutrition 80 (4) 903-910.

Borghans, L., Duckworth, A., Heckman, J., ter Weel, B., 2008. The economics and psychology of personality traits. The Journal of Human Resources 43 (4) 972-1059.

Chang, S.M., Walker, S.P., Grantham-McGregor, S., Powell, C.A., 2002. Early childhood stunting and later behaviour and school achievement. Journal of Child Psychology and Psychiatry and Allied Disciplines 43 (6) 775-783.

Coneus, K., Laucht, M., Reu, K., 2012. The role of parental investments for cognitive and non-cognitive skill formation: evidence for the first 11 years of life. Economics and Human Biology 10(2) 189-209.

Crookston, B., Penny, M., Alder, S., Dickerson, T., Merril, R., Stanford, J., Porucznik, C., Dear- den, K., 2010. Children who recover from early stunting and children who are not stunted demonstrate similar levels of cognition. Journal of Nutrition 140 (11) 19962001.

Crookston, B., Schott, W., Cueto, S., Dearden, K., Engle, P., Georgiadis, A., Lundeen E., Penny M., Stein A., Behrman J., 2013. Postinfancy growth, schooling and cognitive achievement: Young Lives. The American Journal of Clinical Nutrition 98 (6) 15551563.

Cueto, S., Leon, J., 2013. Psychometric characteristics of cognitive development and achievement instruments in Round 3 of Young Lives. Young Lives Technical Note Series 25, University of Oxford.

Cueto, S., Leon, J., Guerrero, G., Munoz, I., 2009. Psychometric characteristics of cognitive development and achievement instruments in Round 2 of Young Lives. Young Lives Working Paper Series 15, University of Oxford.

Cunha, F., Heckman, J.J., 2007. The technology of skill formation. American Economic Review 97 (2) 31-47.

Cunha, F., Heckman, J.J., 2008. Formulating, identifying and estimating the technology of cognitive and noncognitive skill formation. Journal of Human Resources 43 (4) 738782 . 
Cunha, F., Heckman, J.J., Schennach, S.S., 2010. Estimating the technology of cognitive and noncognitive skill formation. Econometrica 78 (3) 883-931.

Dercon, S., Krishnan, P., 2009. Poverty and the psychosocial competencies of children: evidence from the Young Lives sample in four developing countries. Children, Youth and Environments 19 (2) 138-163.

Dercon, S., Outes-Leon, I., 2008. Survey attrition and attrition bias in Young Lives, Young Lives Technical Note 5, University of Oxford.

Dercon, S., Sanchez, A., 2013. Height in mid childhood and psychosocial competencies in late childhood: evidence from four developing countries, Economics and Human Biology, 11 426-432.

Escobal, J., Flores, E., 2008. An assessment of the Young Lives sampling approach in Peru, Young Lives Technical Note 3, University of Oxford.

Favara, M., Sanchez, A. 2017. Psychosocial competencies and risky behaviours in Peru. Journal IZA of Labor and Development, 6(3).

Favara, M., Lavado, P., Sanchez A., 2016. Understanding teenage fertility, cohabitation, and marriage: the case of Peru. IZA Working Paper 10270, IZA.

Galler, J., Cyralene, B., Zichlin, G., Fitzmaurice, D., Eaglesfield D., Waber, D., 2012. Infant malnutrition is associated with persisting attention deficits in middle adulthood. Journal of Nutrition 142 (4) 788-794.

Glewwe, P., Jacoby, H.G., King, E., 2001. Early childhood nutrition and academic achievement: a longitudinal analysis. Journal of Public Economics 81 (3) 345-368.

Goldsmith, A.H., Veum, J.R., Darity, W.J., 1997. The impact of psychological and human capital on wages. Economic Inquiry 35 (4) 815-829.

Grantham-McGregor, S., 1995. A review of studies of the effect of severe malnutrition on mental development. The American Journal of Clinical Nutrition 125 (8 Suppl) 2233S-2238S.

Grantham-McGregor, S.M., Fernald, L., Sethuraman, K., 1999. Effects of health and nutrition on cognitive and behavioural development in children in the first three years of life. Food and Nutrition Bulletin 20 (1) 53-75.

Grantham-McGregor, S., Cheung, Y., Cueto, S., Glewwe, P., Richter, L., Strupp, B., 2007. Developmental potential in the first 5 years for children in developing countries. The Lancet 369 (9555) 60-70.

Helmers, C., Patnam, M., 2011. The formation and evolution of childhood skill acquisition: Evidence from India. Journal of Development Economics 95 (2) 252-266.

Kumra, N., 2008. An assessment of the Young Lives sampling approach in Andhra Pradesh, India, Young Lives Technical Note 2, University of Oxford. 
Levitsky, D., Strupp, B., 1995. Malnutrition and the brain: changing concepts, changing concerns. The American Journal of Clinical Nutrition 125 (8 Suppl) 2212S-2220S13.

Nguyen, N., 2008. An assessment of the Young Lives sampling approach in Vietnam, Young Lives Technical Note 4, University of Oxford.

Outes, I., Sanchez, A., 2008. An assessment of the Young Lives sampling approach in Ethiopia, Young Lives Technical Note 1, University of Oxford.

Pollitt, E., Gorman, K., Engle, P., Martorell, R., Rivera, J., Wachs, T., Scrimshaw, N., 1993. Supplementary feeding and cognition: effects over two decades. Monographs of the Society for Research in Child Development 58 (7) i-118.

Rosenberg, M., 1965. Society and the adolescent self-image. Princeton University Press.

Rotter, J.B., 1965. Generalized expectancies for internal versus external control of reinforcement. Psychol Monogr, 80 (1) 1-28.

Stajkovic, A., Luthans, F., 1998. Self-efficacy and work-related performance: a metaanalysis. Psychological Bulletin 124 (2) 240-261.

Tierney, A., Nelson, C., 2009. Brain development and the role of experience in the early years. Zero Three 30 (2) 9-13.

Todd, P., Wolpin, K., 2003. On the specification and estimation of the production function for cognitive achievement. The Economic Journal 113 (485) F3-F33.

Trzesniewski, K.H., Donnellan, M.B., Robins, R.W., 2003. Stability of self-esteem across the life span. Journal of Personality and Social Psychology 84 (1) 205-220.

Walker, S., Chang, S., Powell, C., Simonoff, E., Grantham-McGregor, S., 2007. Early childhood stunting is associated with poor psychological functioning in late adolescence and effects are reduced by psychosocial stimulation. Journal of Nutrition 137 2464-2469. 
Table 9: Summary statistics

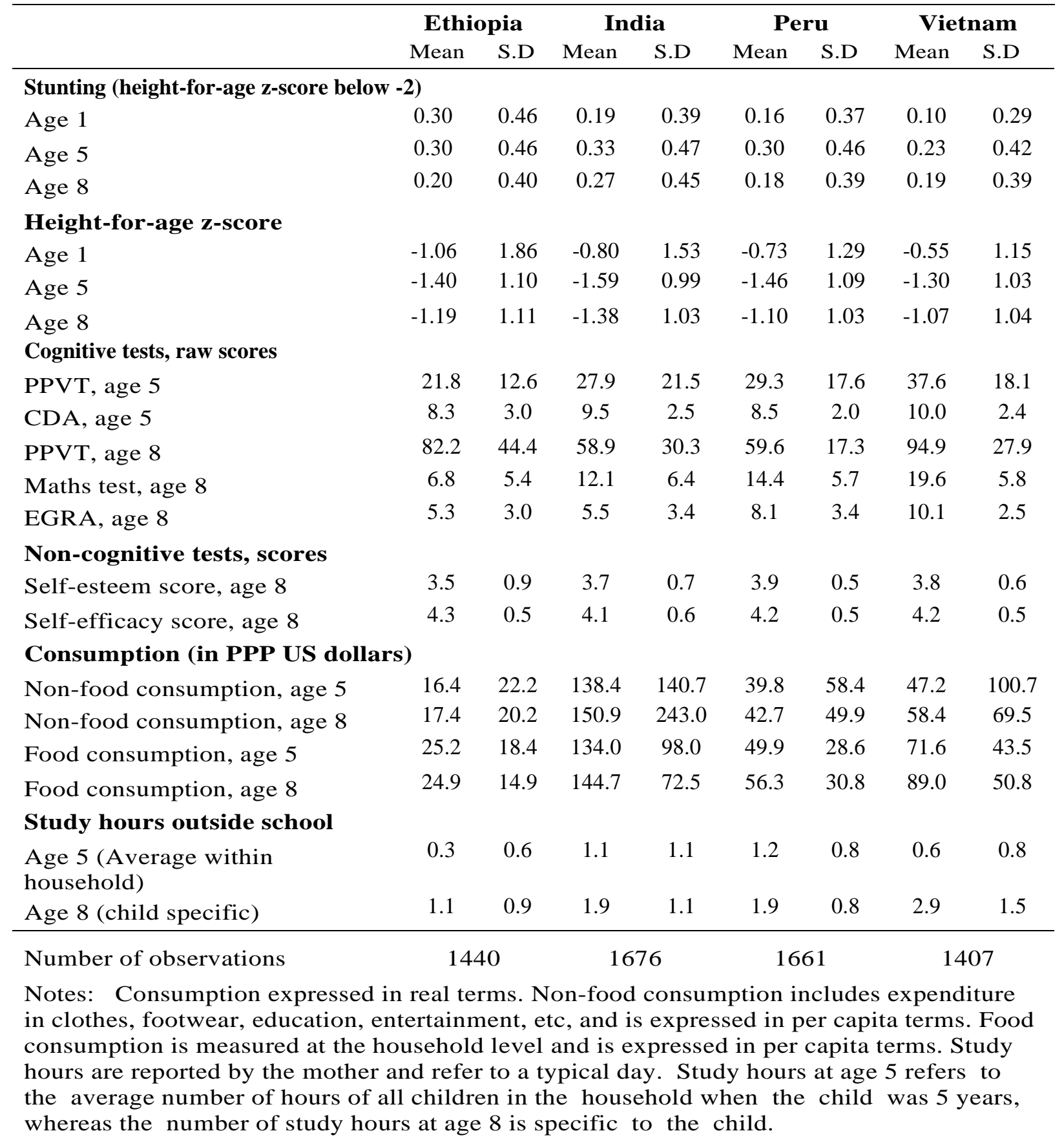


Table 10: Proportion of variance explained by factors

\begin{tabular}{|c|c|c|c|}
\hline & Variable & Factor & $\begin{array}{c}\text { Measurment } \\
\text { error }\end{array}$ \\
\hline \multicolumn{4}{|c|}{ Cognitive skills, age 8} \\
\hline \multirow[t]{3}{*}{ Ethiopia } & PPVT & 0.492 & 0.508 \\
\hline & Maths test & 0.819 & 0.181 \\
\hline & EGRA & 0.578 & 0.422 \\
\hline \multirow[t]{3}{*}{ India } & PPVT & 0.338 & 0.662 \\
\hline & Maths test & 0.734 & 0.266 \\
\hline & EGRA & 0.598 & 0.402 \\
\hline \multirow[t]{3}{*}{ Peru } & PPVT & 0.645 & 0.355 \\
\hline & Maths test & 0.627 & 0.373 \\
\hline & EGRA & 0.675 & 0.325 \\
\hline \multirow[t]{3}{*}{ Vietnam } & PPVT & 0.373 & 0.627 \\
\hline & Maths test & 0.601 & 0.399 \\
\hline & EGRA & 0.421 & 0.579 \\
\hline \multicolumn{4}{|c|}{ Cognitive skills, age 5} \\
\hline \multirow[t]{2}{*}{ Ethiopia } & PPVT & 0.456 & 0.544 \\
\hline & CDA & 0.48 & 0.52 \\
\hline \multirow[t]{2}{*}{ India } & PPVT & 0.451 & 0.549 \\
\hline & CDA & 0.473 & 0.527 \\
\hline \multirow[t]{2}{*}{ Peru } & PPVT & 0.501 & 0.499 \\
\hline & $\mathrm{CDA}$ & 0.541 & 0.459 \\
\hline \multirow{2}{*}{ Vietnam } & PPVT & 0.516 & 0.484 \\
\hline & CDA & 0.536 & 0.464 \\
\hline \multicolumn{4}{|c|}{ Non-cognitive skills, age 8} \\
\hline \multirow[t]{2}{*}{ Ethiopia } & Self-esteem & 0.269 & 0.731 \\
\hline & Self-efficacy & 0.269 & 0.731 \\
\hline \multirow[t]{2}{*}{ India } & Self-esteem & 0.368 & 0.632 \\
\hline & Self-efficacy & 0.368 & 0.632 \\
\hline \multirow[t]{2}{*}{ Peru } & Self-esteem & 0.396 & 0.604 \\
\hline & Self-efficacy & 0.396 & 0.604 \\
\hline \multirow[t]{2}{*}{ Vietnam } & Self-esteem & 0.313 & 0.687 \\
\hline & Self-efficacy & 0.314 & 0.686 \\
\hline \multicolumn{4}{|c|}{ Parental investments in skills, age 8} \\
\hline \multirow[t]{4}{*}{ Ethiopia } & Log expenditure on children's education & 0.192 & 0.808 \\
\hline & Log expenditure on children's clothes & 0.866 & 0.134 \\
\hline & Number of hours child studies outside school & 0.13 & 0.87 \\
\hline & Quality of relationship between child and parents & 0 & 1 \\
\hline \multirow[t]{4}{*}{ India } & Log expenditure on children's education & 0.405 & 0.595 \\
\hline & Log expenditure on children's clothes & 0.627 & 0.373 \\
\hline & Number of hours child studies outside school & 0.134 & 0.866 \\
\hline & Quality of relationship between child and parents & 0.004 & 0.996 \\
\hline \multirow[t]{4}{*}{ Peru } & Log expenditure on children's education & 0.336 & 0.664 \\
\hline & Log expenditure on children's clothes & 0.829 & 0.171 \\
\hline & Number of hours child studies outside school & 0.099 & 0.901 \\
\hline & Quality of relationship between child and parents & 0.014 & 0.986 \\
\hline \multirow[t]{3}{*}{ Vietnam } & Log expenditure on children's clothes and education & 0.274 & 0.726 \\
\hline & Number of hours child studies outside school & 0.516 & 0.484 \\
\hline & Quality of relationship between child and parents & 0.043 & 0.957 \\
\hline
\end{tabular}




\begin{tabular}{|c|c|c|c|}
\hline \multicolumn{2}{|c|}{ Parental investments in skills, age 5} & \multirow{2}{*}{$\begin{array}{c}\text { Factor } \\
0.154 \\
\end{array}$} & \multirow{2}{*}{$\begin{array}{c}\begin{array}{c}\text { Measurment } \\
\text { error }\end{array} \\
0.846 \\
\end{array}$} \\
\hline Ethiopia & Log expenditure on children's clothes & & \\
\hline & $\begin{array}{l}\text { Ing exnenditure on children's education } \\
\text { Average number of hours children study outside school }\end{array}$ & $\begin{array}{l}0.914 \\
0.255\end{array}$ & $\begin{array}{l}0.086 \\
0.745\end{array}$ \\
\hline \multirow{3}{*}{ India } & Log expenditure on children's clothes & 0.209 & 0.791 \\
\hline & Log expenditure on children's education & 0.943 & 0.057 \\
\hline & Average number of hours children study outside school & 0.134 & 0.866 \\
\hline \multirow{3}{*}{ Peru } & Log expenditure on children's clothes & 0.191 & 0.809 \\
\hline & Log expenditure on children's education & 0.876 & 0.124 \\
\hline & Average number of hours children study outside school & 0.196 & 0.804 \\
\hline \multirow[t]{2}{*}{ Vietnam } & Log expenditure on children's clothes & 0.128 & 0.872 \\
\hline & $\begin{array}{l}\text { Log expenditure on children's education } \\
\text { Average number of hours children study outside school }\end{array}$ & $\begin{array}{l}0.809 \\
0.158\end{array}$ & $\begin{array}{l}0.191 \\
0.842\end{array}$ \\
\hline \multicolumn{4}{|c|}{ Parental investments in nutrition, age 8} \\
\hline \multirow[t]{4}{*}{ Ethiopia } & Log consumption of proteins & 0.129 & 0.871 \\
\hline & Log consumption of carbohydrates & 0.423 & 0.577 \\
\hline & Log consumption of lipids and other food types & 0.782 & 0.218 \\
\hline & Log consumption of minerals and vitamins & 0.138 & 0.862 \\
\hline \multirow[t]{4}{*}{ India } & Log consumption of proteins & 0.371 & 0.629 \\
\hline & Log consumption of carbohydrates & 0.541 & 0.459 \\
\hline & Log consumption of lipids and other food types & 0.646 & 0.354 \\
\hline & Log consumption of minerals and vitamins & 0.468 & 0.532 \\
\hline \multirow[t]{4}{*}{ Peru } & Log consumption of proteins & 0.531 & 0.469 \\
\hline & Log consumption of carbohydrates & 0.511 & 0.489 \\
\hline & Log consumption of lipids and other food types & 0.419 & 0.581 \\
\hline & Log consumption of minerals and vitamins & 0.464 & 0.536 \\
\hline \multirow[t]{4}{*}{ Vietnam } & Log consumption of proteins & 0.538 & 0.462 \\
\hline & Log consumption of carbohydrates & 0.379 & 0.621 \\
\hline & Log consumption of lipids and other food types & 0.456 & 0.544 \\
\hline & Log consumption of minerals and vitamins & 0.551 & 0.449 \\
\hline \multicolumn{4}{|c|}{ Parental investments in nutrition, age 5} \\
\hline \multirow[t]{4}{*}{ Ethiopia } & Log consumption of proteins & 0.142 & 0.858 \\
\hline & Log consumption of carbohydrates & 0.361 & 0.639 \\
\hline & Log consumption of lipids and other food types & 0.692 & 0.308 \\
\hline & Log consumption of minerals and vitamins & 0.068 & 0.932 \\
\hline \multirow[t]{4}{*}{ India } & Log consumption of proteins & 0.261 & 0.739 \\
\hline & Log consumption of carbohydrates & 0.267 & 0.733 \\
\hline & Log consumption of lipids and other food types & 0.607 & 0.393 \\
\hline & Log consumption of minerals and vitamins & 0.416 & 0.584 \\
\hline \multirow[t]{4}{*}{ Peru } & Log consumption of proteins & 0.574 & 0.426 \\
\hline & Log consumption of carbohydrates & 0.406 & 0.594 \\
\hline & Log consumption of lipids and other food types & 0.52 & 0.48 \\
\hline & Log consumption of minerals and vitamins & 0.446 & 0.554 \\
\hline \multirow[t]{4}{*}{ Vietnam } & Log consumption of proteins & 0.661 & 0.339 \\
\hline & Log consumption of carbohydrates & 0.152 & 0.848 \\
\hline & Log consumption of lipids and other food types & 0.364 & 0.636 \\
\hline & Log consumption of minerals and vitamins & 0.476 & 0.524 \\
\hline
\end{tabular}


Table 11: Main model reported infull detail

\begin{tabular}{|c|c|c|c|c|c|c|c|c|c|c|c|c|}
\hline & \multicolumn{3}{|c|}{ Ethiopia } & \multicolumn{3}{|c|}{ India } & \multicolumn{3}{|c|}{ Peru } & \multicolumn{3}{|c|}{ Vietnam } \\
\hline & Coef & Std. Err. & $\mathrm{p}$ & Coef & Std. Err. & $\mathrm{p}$ & Coef & Std. Err. & $\mathrm{p}$ & Coef & Std. Err. & $\mathrm{p}$ \\
\hline \multicolumn{13}{|c|}{ Dependent variable: cognitive skills, age 8} \\
\hline Cognitive skills, age 5 & 0.128 & 0.019 & 0 & 0.22 & 0.026 & 0 & 0.264 & 0.033 & 0 & 0.206 & 0.035 & 0 \\
\hline Height-for-age, age 5 & 0.112 & 0.022 & 0 & 0.109 & 0.026 & 0 & 0.102 & 0.02 & 0 & 0.105 & 0.024 & 0 \\
\hline Parental investment, age 8 & 0.252 & 0.024 & 0 & 0.117 & 0.037 & 0.002 & 0.178 & 0.026 & 0 & 0.158 & 0.042 & 0 \\
\hline Mother's years of education & 0.109 & 0.027 & 0 & 0.211 & 0.026 & 0 & 0.246 & 0.032 & 0 & 0.252 & 0.034 & 0 \\
\hline Born in rural area & -0.272 & 0.049 & 0 & 0.08 & 0.042 & 0.06 & -0.159 & 0.037 & 0 & -0.051 & 0.075 & 0.502 \\
\hline Region 2 & -0.084 & 0.033 & 0.011 & 0.232 & 0.063 & 0 & 0.027 & 0.047 & 0.565 & 0.006 & 0.08 & 0.939 \\
\hline Region 3 & -0.221 & 0.042 & 0 & -0.185 & 0.051 & 0 & 0.081 & 0.039 & 0.038 & 0.102 & 0.105 & 0.333 \\
\hline Region 4 & -0.155 & 0.062 & 0.012 & & & & & & & 0.037 & 0.065 & 0.569 \\
\hline Year of bitth is 2002 & -0.067 & 0.022 & 0.002 & -0.048 & 0.027 & 0.078 & -0.127 & 0.015 & 0 & -0.226 & 0.031 & 0 \\
\hline Constant & 0.715 & 0.084 & 0 & -0.118 & 0.088 & 0.181 & -0.153 & 0.096 & 0.11 & -0.2 & 0.242 & 0.408 \\
\hline \multicolumn{13}{|c|}{ Dependent variable: non-cognitive skills, age 8} \\
\hline Cognitive skills, age 5 & -0.031 & 0.035 & 0.369 & 0.089 & 0.028 & 0.002 & 0.109 & 0.029 & 0 & 0.138 & 0.034 & 0 \\
\hline Height-for-age, age 5 & 0.033 & 0.032 & 0.302 & 0.039 & 0.02 & 0.053 & 0.032 & 0.025 & 0.196 & 0.006 & 0.02 & 0.775 \\
\hline Parental investment, age 8 & 0.11 & 0.052 & 0.035 & 0.177 & 0.037 & 0 & 0.076 & 0.022 & 0.001 & 0.143 & 0.046 & 0.002 \\
\hline Mother's years of education & 0.037 & 0.037 & 0.305 & 0.129 & 0.034 & 0 & 0.087 & 0.031 & 0.005 & 0.099 & 0.04 & 0.014 \\
\hline Born in rural area & -0.083 & 0.087 & 0.34 & -0.108 & 0.054 & 0.046 & -0.117 & 0.032 & 0 & -0.024 & 0.064 & 0.705 \\
\hline Region 2 & -0.132 & 0.059 & 0.024 & -0.062 & 0.035 & 0.075 & -0.011 & 0.028 & 0.683 & -0.22 & 0.043 & 0 \\
\hline Region 3 & -0.032 & 0.065 & 0.616 & -0.064 & 0.057 & 0.262 & -0.015 & 0.02 & 0.45 & -0.171 & 0.063 & 0.007 \\
\hline Region 4 & -0.181 & 0.068 & 0.008 & & & & & & & 0.099 & 0.036 & 0.006 \\
\hline Year of bitth is 2002 & -0.05 & 0.023 & 0.032 & -0.016 & 0.018 & 0.362 & 0.002 & 0.019 & 0.917 & 0.037 & 0.023 & 0.106 \\
\hline Constant & 0.349 & 0.213 & 0.101 & 0.25 & 0.129 & 0.052 & -0.017 & 0.078 & 0.827 & 0.046 & 0.199 & 0.818 \\
\hline \multicolumn{13}{|c|}{ Dependent variable: cognitive skills, age 5} \\
\hline Height-for-age, age 1 & 0.073 & 0.022 & 0.001 & 0.15 & 0.023 & 0 & 0.091 & 0.025 & 0 & 0.101 & 0.028 & 0 \\
\hline Parental investment, age 5 & 0.145 & 0.03 & 0 & 0.098 & 0.031 & 0.001 & 0.242 & 0.018 & 0 & 0.093 & 0.058 & 0.11 \\
\hline Mother's years of education & 0.264 & 0.049 & 0 & 0.303 & 0.021 & 0 & 0.24 & 0.036 & 0 & 0.236 & 0.063 & 0 \\
\hline Born in rural area & -0.145 & 0.039 & 0 & -0.061 & 0.097 & 0.531 & -0.078 & 0.042 & 0.067 & -0.233 & 0.132 & 0.077 \\
\hline Region 2 & -0.182 & 0.058 & 0.002 & -0.047 & 0.1 & 0.642 & -0.016 & 0.059 & 0.79 & 0.065 & 0.129 & 0.614 \\
\hline Region 3 & -0.009 & 0.045 & 0.846 & -0.046 & 0.105 & 0.661 & -0.025 & 0.045 & 0.571 & -0.049 & 0.177 & 0.781 \\
\hline Region 4 & -0.03 & 0.056 & 0.59 & & & & & & & -0.067 & 0.07 & 0.34 \\
\hline Year of bith is 2002 & -0.098 & 0.021 & 0 & -0.078 & 0.028 & 0.005 & -0.011 & 0.033 & 0.744 & -0.109 & 0.02 & 0 \\
\hline Constant & 0.232 & 0.102 & 0.022 & 0.081 & 0.267 & 0.763 & -0.278 & 0.137 & 0.042 & 0.268 & 0.412 & 0.515 \\
\hline CONTINUES ON NEXT & GE & & & & & & & & & & & \\
\hline
\end{tabular}


Ethiopia

India

Peru

Vietnam

\begin{tabular}{|c|c|c|c|c|c|c|c|c|c|c|c|c|}
\hline & \multicolumn{3}{|c|}{ Ethiopia } & \multicolumn{3}{|c|}{ India } & \multicolumn{3}{|c|}{ Peru } & \multicolumn{3}{|c|}{ Vietnam } \\
\hline & Coef & Std. Err. & $\mathrm{p}$ & Coef & Std. & $\mathrm{p}$ & Coef & Std. & $\mathrm{p}$ & Coef & Std. Err. & $\mathrm{p}$ \\
\hline \multicolumn{13}{|c|}{ Dependent variable: height-for-age, age 8} \\
\hline Cognitive skills, age 5 & 0.057 & 0.033 & 0.085 & -0.05 & 0.024 & 0.037 & 0.039 & 0.019 & 0.044 & 0.048 & 0.022 & 0.027 \\
\hline Height-for-age, age 5 & 0.644 & 0.036 & 0 & 0.725 & 0.026 & 0 & 0.754 & 0.019 & 0 & 0.808 & 0.047 & 0 \\
\hline Mother's years of education & -0.025 & 0.021 & 0.233 & 0.07 & 0.018 & 0 & 0.064 & 0.018 & 0 & 0.003 & 0.024 & 0.912 \\
\hline Born in rural area & -0.036 & 0.043 & 0.393 & -0.088 & 0.037 & 0.017 & 0.004 & 0.032 & 0.911 & -0.011 & 0.025 & 0.673 \\
\hline Region 2 & 0.013 & 0.03 & 0.661 & -0.046 & 0.042 & 0.27 & -0.023 & 0.033 & 0.478 & 0.069 & 0.015 & 0 \\
\hline Region 3 & 0.068 & 0.047 & 0.15 & -0.045 & 0.039 & 0.248 & 0.021 & 0.033 & 0.537 & 0.021 & 0.02 & 0.307 \\
\hline Year of birth is 2002 & 0.006 & 0.018 & 0.757 & 0.005 & 0.018 & 0.797 & 0.023 & 0.014 & 0.098 & 0.023 & 0.015 & 0.137 \\
\hline Constant & -0.231 & 0.074 & 0.002 & -0.018 & 0.114 & 0.876 & -0.182 & 0.051 & 0 & -0.03 & 0.105 & 0.776 \\
\hline \multicolumn{13}{|c|}{ Dependent variable: height-for-age, age 5} \\
\hline Height-for-age, age 1 & 0.393 & 0.062 & 0 & 0.525 & 0.04 & 0 & 0.51 & 0.028 & 0 & 0.6 & 0.025 & 0 \\
\hline Parental investment in nutrition, age 5 & 0.027 & 0.032 & 0.401 & 0.115 & 0.035 & 0.001 & 0.076 & 0.026 & 0.004 & 0.107 & 0.027 & 0 \\
\hline Mother's years of education & 0.139 & 0.045 & 0.002 & 0.059 & 0.028 & 0.034 & 0.154 & 0.029 & 0 & 0.113 & 0.026 & 0 \\
\hline Born in rural area & -0.054 & 0.077 & 0.484 & -0.102 & 0.032 & 0.001 & -0.117 & 0.025 & 0 & -0.132 & 0.037 & 0 \\
\hline Region 2 & 0.009 & 0.043 & 0.836 & -0.132 & 0.05 & 0.009 & -0.07 & 0.032 & 0.028 & -0.002 & 0.03 & 0.943 \\
\hline Region 3 & -0.074 & 0.097 & 0.445 & -0.101 & 0.032 & 0.002 & -0.05 & 0.024 & 0.033 & 0.013 & 0.033 & 0.699 \\
\hline Year of birth is 2002 & -0.036 & 0.025 & 0.152 & -0.075 & 0.021 & 0 & -0.119 & 0.025 & 0 & -0.137 & 0.015 & 0 \\
\hline Constant & -1.02 & 0.126 & 0 & -0.993 & 0.098 & 0 & -1.075 & 0.096 & 0 & -0.912 & 0.125 & 0 \\
\hline \multicolumn{13}{|c|}{ Dependent variable: height-for-age, age 1} \\
\hline Mother's years of education & 0.093 & 0.044 & 0.033 & 0.131 & 0.019 & 0 & 0.255 & 0.031 & 0 & 0.225 & 0.036 & 0 \\
\hline Born in rural area & -0.085 & 0.071 & 0.232 & -0.073 & 0.039 & 0.062 & -0.051 & 0.036 & 0.16 & -0.114 & 0.04 & 0.005 \\
\hline Loss of job/income source & -0.001 & 0.037 & 0.975 & 0.035 & 0.017 & 0.042 & 0.013 & 0.023 & 0.58 & -0.028 & 0.02 & 0.155 \\
\hline Severe illness or injury of hh. member & -0.019 & 0.03 & 0.527 & -0.037 & 0.032 & 0.252 & -0.007 & 0.016 & 0.683 & -0.017 & 0.029 & 0.547 \\
\hline Birth of new hh. member & -0.045 & 0.024 & 0.063 & -0.021 & 0.022 & 0.339 & 0.005 & 0.02 & 0.789 & -0.056 & 0.023 & 0.016 \\
\hline Natural disaster & 0.055 & 0.048 & 0.246 & 0.04 & 0.029 & 0.157 & & & & 0.045 & 0.018 & 0.014 \\
\hline Crop failure & 0.056 & 0.066 & 0.396 & 0.007 & 0.024 & 0.767 & & & & 0.001 & 0.032 & 0.987 \\
\hline Age in months, Round 1 & -0.16 & 0.042 & 0 & -0.32 & 0.029 & 0 & -0.305 & 0.032 & 0 & -0.301 & 0.024 & 0 \\
\hline Region 2 & -0.131 & 0.05 & 0.009 & 0.226 & 0.05 & 0 & -0.23 & 0.034 & 0 & 0.096 & 0.036 & 0.008 \\
\hline Region 3 & -0.103 & 0.084 & 0.22 & -0.053 & 0.036 & 0.142 & -0.08 & 0.038 & 0.039 & 0.189 & 0.038 & 0 \\
\hline Region 4 & -0.018 & 0.086 & 0.831 & & & & & & & 0.249 & 0.035 & 0 \\
\hline Year of birth is 2002 & 0.169 & 0.045 & 0 & -0.084 & 0.028 & 0.003 & -0.02 & 0.036 & 0.585 & -0.071 & 0.04 & 0.08 \\
\hline Constant & -0.007 & 0.234 & 0.977 & 0.581 & 0.119 & 0 & 0.27 & 0.164 & 0.099 & 0.24 & 0.181 & 0.185 \\
\hline CONTINUES ON NEXT PAGE & & & & & & & & & & & & \\
\hline
\end{tabular}




\begin{tabular}{|c|c|c|c|c|c|c|c|c|c|c|c|c|}
\hline & \multicolumn{3}{|c|}{ Ethiopia } & \multicolumn{3}{|c|}{ India } & \multicolumn{3}{|c|}{ Peru } & \multicolumn{3}{|c|}{ Vietnam } \\
\hline & Coef & Std. Err. & $\mathrm{p}$ & Coef & Std. Err. & $\mathrm{p}$ & Coef & Std. Err. & $\mathrm{p}$ & Coef & Std. Err. & $\mathrm{p}$ \\
\hline \multicolumn{13}{|c|}{ Dependent variable: parental investments in skills, age 8} \\
\hline Mother's years of education & 0.307 & 0.048 & 0.000 & 0.415 & 0.030 & 0.000 & 0.404 & 0.036 & 0.000 & 0.338 & 0.058 & 0.000 \\
\hline Born in rural area & -0.325 & 0.077 & 0.000 & -0.041 & 0.062 & 0.506 & -0.058 & 0.058 & 0.314 & -0.243 & 0.071 & 0.001 \\
\hline Negative change in input prices & -0.005 & 0.028 & 0.867 & -0.043 & 0.026 & 0.102 & -0.013 & 0.029 & 0.663 & -0.009 & 0.028 & 0.739 \\
\hline Negative change in output prices & 0.024 & 0.014 & 0.086 & & & & -0.020 & 0.030 & 0.511 & 0.010 & 0.029 & 0.746 \\
\hline Death of livestock & 0.044 & 0.020 & 0.026 & 0.009 & 0.021 & 0.663 & & & & -0.031 & 0.016 & 0.056 \\
\hline Drought & -0.101 & 0.053 & 0.056 & 0.103 & 0.045 & 0.022 & -0.048 & 0.019 & 0.012 & 0.068 & 0.040 & 0.094 \\
\hline Flood or too much rain & 0.006 & 0.024 & 0.804 & -0.006 & 0.045 & 0.898 & & & & -0.018 & 0.029 & 0.530 \\
\hline Pests or diseases affected crops & 0.031 & 0.018 & 0.079 & 0.024 & 0.028 & 0.391 & & & & -0.002 & 0.027 & 0.929 \\
\hline Crop failure & -0.027 & 0.027 & 0.321 & 0.031 & 0.033 & 0.341 & & & & -0.004 & 0.034 & 0.916 \\
\hline Illness of father & 0.002 & 0.023 & 0.934 & 0.042 & 0.020 & 0.032 & & & & -0.008 & 0.022 & 0.719 \\
\hline Illness of mother & 0.013 & 0.029 & 0.644 & 0.020 & 0.022 & 0.378 & 0.032 & 0.017 & 0.061 & -0.048 & 0.018 & 0.008 \\
\hline Illness of other hh. member & 0.009 & 0.023 & 0.698 & 0.032 & 0.023 & 0.161 & -0.020 & 0.022 & 0.346 & 0.000 & 0.020 & 0.985 \\
\hline Region 2 & -0.123 & 0.049 & 0.012 & 0.233 & 0.077 & 0.003 & -0.072 & 0.091 & 0.431 & 0.337 & 0.113 & 0.003 \\
\hline Region 3 & -0.069 & 0.098 & 0.481 & 0.265 & 0.065 & 0.000 & -0.053 & 0.035 & 0.128 & -0.249 & 0.149 & 0.094 \\
\hline Region 4 & -0.068 & 0.090 & 0.449 & & & & & & & -0.144 & 0.105 & 0.169 \\
\hline Year of birth is 2002 & 0.037 & 0.016 & 0.020 & -0.030 & 0.028 & 0.284 & -0.016 & 0.020 & 0.427 & -0.036 & 0.023 & 0.126 \\
\hline Constant & 0.448 & 0.140 & 0.001 & -0.639 & 0.173 & 0.000 & -0.522 & 0.110 & 0.000 & 0.128 & 0.419 & 0.761 \\
\hline \multicolumn{13}{|c|}{ Dependent variable: parental investments in skills, age 5} \\
\hline Mother's years of education & 0.237 & 0.042 & 0.000 & 0.322 & 0.027 & 0.000 & 0.288 & 0.035 & 0.000 & 0.299 & 0.050 & 0.000 \\
\hline Born in rural area & -0.326 & 0.054 & 0.000 & -0.247 & 0.031 & 0.000 & -0.126 & 0.056 & 0.025 & -0.165 & 0.112 & 0.141 \\
\hline Theft & 0.035 & 0.021 & 0.089 & -0.008 & 0.015 & 0.568 & 0.062 & 0.021 & 0.004 & 0.019 & 0.032 & 0.566 \\
\hline Negative change in input/output prices & 0.025 & 0.018 & 0.174 & 0.000 & 0.028 & 0.989 & 0.028 & 0.023 & 0.227 & -0.043 & 0.036 & 0.226 \\
\hline Loss of job/income source & 0.015 & 0.024 & 0.545 & 0.019 & 0.020 & 0.344 & 0.018 & 0.021 & 0.402 & -0.012 & 0.016 & 0.449 \\
\hline Natural disaster & -0.040 & 0.030 & 0.186 & -0.006 & 0.025 & 0.797 & -0.037 & 0.029 & 0.197 & 0.068 & 0.035 & 0.050 \\
\hline Death of a hh. member & -0.042 & 0.024 & 0.085 & -0.005 & 0.022 & 0.828 & -0.025 & 0.021 & 0.243 & 0.010 & 0.024 & 0.666 \\
\hline Illness of a hh. member & 0.031 & 0.030 & 0.289 & 0.038 & 0.028 & 0.166 & 0.050 & 0.022 & 0.025 & 0.043 & 0.033 & 0.201 \\
\hline Food shortage & -0.110 & 0.024 & 0.000 & -0.120 & 0.024 & 0.000 & -0.095 & 0.021 & 0.000 & -0.062 & 0.028 & 0.028 \\
\hline Region 2 & -0.128 & 0.046 & 0.006 & 0.071 & 0.046 & 0.123 & -0.089 & 0.072 & 0.216 & 0.301 & 0.114 & 0.008 \\
\hline Region 3 & -0.018 & 0.068 & 0.792 & 0.104 & 0.047 & 0.027 & -0.138 & 0.036 & 0.000 & 0.198 & 0.150 & 0.187 \\
\hline Region 4 & -0.004 & 0.056 & 0.949 & & & & & & & 0.190 & 0.110 & 0.085 \\
\hline Year of birth is 2002 & 0.037 & 0.016 & 0.018 & -0.067 & 0.024 & 0.005 & -0.034 & 0.023 & 0.144 & -0.072 & 0.033 & 0.029 \\
\hline Constant & 0.419 & 0.104 & 0.000 & 0.148 & 0.123 & 0.230 & -0.227 & 0.095 & 0.017 & -0.552 & 0.502 & 0.272 \\
\hline
\end{tabular}




\begin{tabular}{|c|c|c|c|c|c|c|c|c|c|c|c|c|}
\hline & \multicolumn{3}{|c|}{ Ethiopia } & \multicolumn{3}{|c|}{ India } & \multicolumn{3}{|c|}{ Peru } & \multicolumn{3}{|c|}{ Vietnam } \\
\hline & Coef & Err. & $\mathrm{p}$ & Coef & Std. Err. & $\mathrm{p}$ & Coef & Std. Err. & $\mathrm{p}$ & Coef & Std. Err. & $\mathrm{p}$ \\
\hline \multicolumn{13}{|c|}{ Dependent variable: parental investments in nutrition, age 8} \\
\hline Mother's years of education & 0.321 & 0.036 & 0.000 & 0.275 & 0.036 & 0.000 & 0.258 & 0.034 & 0.000 & 0.346 & 0.039 & 0.000 \\
\hline Born in rural area & -0.181 & 0.085 & 0.033 & 0.131 & 0.086 & 0.129 & 0.140 & 0.057 & 0.014 & -0.257 & 0.070 & 0.000 \\
\hline Negative change in input prices & 0.019 & 0.030 & 0.526 & -0.047 & 0.030 & 0.116 & -0.027 & 0.031 & 0.386 & 0.047 & 0.020 & 0.022 \\
\hline Negative change in output prices & 0.017 & 0.025 & 0.507 & & & & 0.005 & 0.024 & 0.844 & 0.010 & 0.039 & 0.806 \\
\hline Death of livestock & 0.011 & 0.024 & 0.655 & 0.010 & 0.019 & 0.600 & & & & -0.062 & 0.026 & 0.016 \\
\hline Drought & -0.061 & 0.057 & 0.284 & 0.022 & 0.052 & 0.672 & -0.057 & 0.020 & 0.005 & 0.003 & 0.032 & 0.927 \\
\hline Flood or too much rain & -0.003 & 0.034 & 0.936 & -0.077 & 0.041 & 0.061 & & & & 0.017 & 0.026 & 0.497 \\
\hline Pests or diseases affected crops & 0.047 & 0.020 & 0.020 & 0.036 & 0.031 & 0.241 & & & & -0.047 & 0.023 & 0.043 \\
\hline Crop failure & -0.018 & 0.039 & 0.642 & 0.034 & 0.029 & 0.242 & & & & -0.050 & 0.025 & 0.043 \\
\hline Illness of father & -0.016 & 0.030 & 0.587 & 0.030 & 0.018 & 0.104 & & & & -0.028 & 0.025 & 0.262 \\
\hline Illness of mother & 0.018 & 0.024 & 0.470 & 0.003 & 0.018 & 0.855 & -0.001 & 0.021 & 0.944 & -0.021 & 0.026 & 0.436 \\
\hline Illness of other hh. member & -0.059 & 0.026 & 0.023 & -0.063 & 0.031 & 0.042 & -0.019 & 0.031 & 0.544 & 0.001 & 0.024 & 0.955 \\
\hline Region 2 & -0.137 & 0.083 & 0.099 & 0.146 & 0.082 & 0.076 & -0.063 & 0.078 & 0.420 & -0.294 & 0.069 & 0.000 \\
\hline Region 3 & 0.032 & 0.096 & 0.736 & 0.270 & 0.105 & 0.010 & -0.032 & 0.041 & 0.431 & -0.387 & 0.087 & 0.000 \\
\hline Region 4 & -0.257 & 0.077 & 0.001 & & & & & & & -0.093 & 0.062 & 0.135 \\
\hline Year of birth is 2002 & 0.010 & 0.023 & 0.672 & -0.011 & 0.028 & 0.680 & 0.011 & 0.022 & 0.615 & -0.042 & 0.028 & 0.137 \\
\hline Constant & 0.315 & 0.077 & 0.000 & -0.648 & 0.225 & 0.004 & -0.409 & 0.117 & 0.000 & 0.615 & 0.261 & 0.018 \\
\hline \multicolumn{13}{|c|}{ Dependent variable: parental investments in nutrition, age 5} \\
\hline Mother's years of education & 0.256 & 0.031 & 0.000 & 0.253 & 0.037 & 0.000 & 0.367 & 0.030 & 0.000 & 0.352 & 0.040 & 0.000 \\
\hline Born in rural area & -0.146 & 0.032 & 0.000 & 0.086 & 0.074 & 0.247 & 0.042 & 0.055 & 0.448 & -0.132 & 0.080 & 0.098 \\
\hline Theft & 0.054 & 0.023 & 0.017 & 0.045 & 0.023 & 0.053 & -0.015 & 0.023 & 0.509 & 0.014 & 0.023 & 0.527 \\
\hline Negative change in input/output prices & 0.038 & 0.033 & 0.246 & -0.053 & 0.044 & 0.230 & 0.034 & 0.040 & 0.405 & -0.024 & 0.031 & 0.430 \\
\hline Loss of job/income source & -0.019 & 0.025 & 0.454 & 0.000 & 0.020 & 0.980 & 0.030 & 0.025 & 0.229 & -0.087 & 0.029 & 0.003 \\
\hline Natural disaster & 0.017 & 0.030 & 0.575 & -0.035 & 0.045 & 0.427 & -0.027 & 0.028 & 0.337 & -0.032 & 0.049 & 0.508 \\
\hline Death of a hh. member & 0.007 & 0.026 & 0.773 & 0.009 & 0.019 & 0.644 & -0.013 & 0.024 & 0.583 & -0.007 & 0.021 & 0.742 \\
\hline Illness of a hh. member & 0.004 & 0.032 & 0.903 & 0.015 & 0.030 & 0.612 & -0.049 & 0.022 & 0.028 & -0.034 & 0.022 & 0.114 \\
\hline Food shortage & -0.193 & 0.021 & 0.000 & -0.151 & 0.042 & 0.000 & -0.107 & 0.027 & 0.000 & -0.134 & 0.028 & 0.000 \\
\hline Region 2 & -0.234 & 0.041 & 0.000 & 0.200 & 0.096 & 0.037 & -0.025 & 0.093 & 0.786 & -0.022 & 0.085 & 0.795 \\
\hline Region 3 & -0.053 & 0.043 & 0.215 & 0.384 & 0.084 & 0.000 & 0.020 & 0.040 & 0.616 & 0.108 & 0.106 & 0.308 \\
\hline Region 4 & -0.340 & 0.051 & 0.000 & & & & & & & 0.147 & 0.064 & 0.022 \\
\hline Year of birth is 2002 & -0.069 & 0.021 & 0.001 & 0.009 & 0.032 & 0.781 & 0.005 & 0.021 & 0.808 & 0.013 & 0.022 & 0.562 \\
\hline Constant & 0.493 & 0.081 & 0.000 & -0.691 & 0.198 & 0.000 & -0.571 & 0.133 & 0.000 & -0.339 & 0.263 & 0.197 \\
\hline Number of observations & & 1440 & & & 1676 & & & 1661 & & & 1407 & \\
\hline
\end{tabular}


Table 12: Model of skill formation: simulating impact of improvements in nutritional inputs at age 1 on skills at age 8

\begin{tabular}{|c|c|c|c|c|}
\hline & $\begin{array}{c}\text { Ethiopia } \\
\text { (1) }\end{array}$ & $\begin{array}{c}\text { India } \\
\text { (2) }\end{array}$ & $\begin{array}{l}\text { Peru } \\
\text { (3) }\end{array}$ & $\begin{array}{l}\text { Vietnam } \\
\text { (4) }\end{array}$ \\
\hline \multicolumn{5}{|l|}{ Total effects on cognitive skills at age 8} \\
\hline Having a flush toilet, age 1 & $\begin{array}{l}-0.002 * \\
(0.001)\end{array}$ & $\begin{array}{l}0.007 * \\
(0.004)\end{array}$ & $\begin{array}{l}0.007 * * \\
(0.004)\end{array}$ & $\begin{array}{l}0.007 * * \\
(0.003)\end{array}$ \\
\hline Having a pit latrine, age 1 & $\begin{array}{l}0.004 \\
(0.003)\end{array}$ & $\begin{array}{l}0 \\
(0.003)\end{array}$ & $\begin{array}{l}0 \\
(0.003)\end{array}$ & $\begin{array}{l}0.004 \\
(0.003)\end{array}$ \\
\hline Water piped into dwelling, age 1 & $\begin{array}{l}0.003 \\
(0.002)\end{array}$ & $\begin{array}{l}0.002 \\
(0.003)\end{array}$ & $\begin{array}{l}0 \\
(0.002)\end{array}$ & $\begin{array}{l}0.005 \\
(0.003)\end{array}$ \\
\hline Water public standpipe, age 1 & $\begin{array}{l}0.003 \\
(0.002)\end{array}$ & $\begin{array}{l}0.004 \\
(0.003)\end{array}$ & $\begin{array}{l}-0.002 \\
(0.001)\end{array}$ & $\begin{array}{l}-0.002 \\
(0.002)\end{array}$ \\
\hline Number of antenatal visits & $\begin{array}{l}0.001 \\
(0.002)\end{array}$ & $\begin{array}{l}0.002 \\
(0.003)\end{array}$ & $\begin{array}{l}0.005 * * \\
(0.002)\end{array}$ & $\begin{array}{l}0.006^{* *} \\
(0.003)\end{array}$ \\
\hline Second food consumption auintile. age 1 & & & $\begin{array}{l}0.004 * \\
(0.002)\end{array}$ & \\
\hline Third food consumption quintile, age 1 & & & $\begin{array}{l}0.004 \\
(0.002)\end{array}$ & \\
\hline Fourth food consumption quintile, age 1 & & & $\begin{array}{l}0.005^{* *} \\
(0.002)\end{array}$ & \\
\hline Fifth food consumption quintile, age 1 & & & $\begin{array}{l}0.006^{* *} \\
(0.003)\end{array}$ & \\
\hline \multicolumn{5}{|l|}{ Total effects on non-cognitive skills at age 8} \\
\hline Having a flush toilet, age 1 & $\begin{array}{l}0 \\
(0.001)\end{array}$ & $\begin{array}{l}0.003 * \\
(0.002)\end{array}$ & $\begin{array}{l}0.002 \\
(0.002)\end{array}$ & $\begin{array}{l}0.002 \\
(0.001)\end{array}$ \\
\hline Having a pit latrine, age 1 & $\begin{array}{l}0.001 \\
(0.001)\end{array}$ & $\begin{array}{l}0.001 \\
(0.001)\end{array}$ & $\begin{array}{l}0 \\
(0.001)\end{array}$ & $\begin{array}{l}0.001 \\
(0.001)\end{array}$ \\
\hline Water piped into dwelling, age 1 & $\begin{array}{l}0.001 \\
(0.001)\end{array}$ & $\begin{array}{l}0.001 \\
(0.001)\end{array}$ & $\begin{array}{l}0 \\
(0.001)\end{array}$ & $\begin{array}{l}0.001 \\
(0.001)\end{array}$ \\
\hline Water public standpipe, age 1 & $\begin{array}{l}0.001 \\
(0.001)\end{array}$ & $\begin{array}{l}-0.001 \\
(0.001)\end{array}$ & $\begin{array}{l}0.001 \\
(0.000)\end{array}$ & $\begin{array}{l}0 \\
(0.001)\end{array}$ \\
\hline Number of antenatal visits & $\begin{array}{l}0.000 \\
(0.000)\end{array}$ & $\begin{array}{l}0.001 \\
(0.001)\end{array}$ & $\begin{array}{l}0.001 \\
(0.001)\end{array}$ & $\begin{array}{l}0.001 \\
(0.001)\end{array}$ \\
\hline Second food consumption quintile, age 1 & & & $\begin{array}{l}0.001 \\
(0.001)\end{array}$ & \\
\hline Third food consumption quintile, age 1 & & & $\begin{array}{l}0.001 \\
(0.001)\end{array}$ & \\
\hline Fourth food consumption quintile, age 1 & & & $\begin{array}{l}0.002 * \\
(0.001)\end{array}$ & \\
\hline Fifth food consumption quintile, age 1 & & & $\begin{array}{l}0.002 \\
(0.001)\end{array}$ & \\
\hline \multicolumn{5}{|l|}{ Total effects on height-for-age at age 8} \\
\hline Having a flush toilet, age 1 & -0.011 & $0.031 *$ & $0.038 * *$ & $0.042 * * *$ \\
\hline Having a pit latrine. age 1 & $\begin{array}{l}(0.006) \\
0.023^{*} \\
(0.012)\end{array}$ & $\begin{array}{l}(0.018) \\
0.002 \\
(0.011)\end{array}$ & $\begin{array}{l}(0.016) \\
0.000 \\
(0.018)\end{array}$ & $\begin{array}{l}(0.016) \\
0.026 \\
(0.016)\end{array}$ \\
\hline Water piped into dwelling, age 1 & $\begin{array}{l}0.014 \\
(0.01)\end{array}$ & $\begin{array}{l}0.009 \\
(0.011)\end{array}$ & $\begin{array}{l}-0.002 \\
(0.012)\end{array}$ & $\begin{array}{l}0.030^{*} \\
(0.018)\end{array}$ \\
\hline Water public standpipe, age 1 & $\begin{array}{l}0.016 \\
(0.012)\end{array}$ & $\begin{array}{l}-0.016 \\
(0.014)\end{array}$ & $\begin{array}{l}-0.01 \\
(0.007)\end{array}$ & $\begin{array}{l}-0.01 \\
(0.009)\end{array}$ \\
\hline Number of antenatal visits & $\begin{array}{l}-0.003 \\
(0.008)\end{array}$ & $\begin{array}{l}0.008 \\
(0.012)\end{array}$ & $\begin{array}{l}0.027 * * \\
(0.013)\end{array}$ & $\begin{array}{l}0.036 * * * \\
(0.014)\end{array}$ \\
\hline Second food consumption quintile, age 1 & & & $\begin{array}{l}0.020 * * \\
(0.01)\end{array}$ & \\
\hline Third food consumption quintile, age 1 & & & $\begin{array}{l}0.019^{*} \\
(0.011)\end{array}$ & \\
\hline Fourth food consumption quintile, age 1 & & & $\begin{array}{l}0.028 * * \\
(0.011)\end{array}$ & \\
\hline Fifth food consumption quintile, age 1 & & & $\begin{array}{l}0.031 * * * \\
(0.01)\end{array}$ & \\
\hline $\mathrm{N}$ & 1440 & 1676 & 1661 & 1407 \\
\hline
\end{tabular}

Notes: Standardized coefficients reported. Standard errors obtained by the Delta method are reported.* indicates significance at $10 \%$; ** at $5 \%$; *** at $1 \%$. 


\section{Supplementary Material: Part A}

Table A.1: Model of skill formation: alternative results without instrumental variables

\begin{tabular}{|c|c|c|c|c|}
\hline & $\begin{array}{l}\text { Ethiopia } \\
\text { (1) }\end{array}$ & $\begin{array}{l}\text { India } \\
(2)\end{array}$ & $\begin{array}{c}\text { Peru } \\
(3)\end{array}$ & $\begin{array}{l}\text { Vietnam } \\
\text { (4) }\end{array}$ \\
\hline \multirow{2}{*}{\multicolumn{5}{|c|}{$\begin{array}{l}\text { PANEL A } \\
\text { Dependent variable: cognitive skills, age } 8\end{array}$}} \\
\hline & & & & \\
\hline Cognitive skill, age 5 & $\begin{array}{c}0.128 * * * \\
(0.020)\end{array}$ & $\begin{array}{l}0.220 * * * \\
(0.026)\end{array}$ & $\begin{array}{c}0.263 * * * \\
(0.034)\end{array}$ & $\begin{array}{c}0.206^{* * *} \\
(0.035)\end{array}$ \\
\hline Height-for-age, age 5 & $\begin{array}{l}0.112 * * * \\
(0.021)\end{array}$ & $\begin{array}{c}0.109 * * * \\
(0.025)\end{array}$ & $\begin{array}{l}0.102 * * * \\
(0.021)\end{array}$ & $\begin{array}{l}0.105^{* * *} \\
(0.024)\end{array}$ \\
\hline Parental investments, age 8 & $\begin{array}{c}0.251 * * * \\
(0.023)\end{array}$ & $\begin{array}{c}0.117 * * * \\
(0.034)\end{array}$ & $\begin{array}{c}0.178^{* * * *} \\
(0.027)\end{array}$ & $\begin{array}{c}0.158 * * * \\
(0.039)\end{array}$ \\
\hline \multicolumn{5}{|c|}{ Dependent variable: non-cognitive skills, age 8} \\
\hline Cognitive skill, age 5 & $\begin{array}{c}-0.031 \\
(0.035)\end{array}$ & $\begin{array}{r}0.089 * * * \\
(0.028)\end{array}$ & $\begin{array}{r}0.109 * * * \\
(0.029)\end{array}$ & $\begin{array}{r}0.138 * * * \\
(0.033)\end{array}$ \\
\hline Height-for-age, age 5 & $\begin{array}{c}0.033 \\
(0.032)\end{array}$ & $\begin{array}{l}0.039 * \\
(0.020)\end{array}$ & $\begin{array}{c}0.032 \\
(0.025)\end{array}$ & $\begin{array}{l}0.006 \\
(0.020)\end{array}$ \\
\hline Parental investments, age 8 & $\begin{array}{c}0.110 * * \\
(0.051)\end{array}$ & $\begin{array}{c}0.176 * * * \\
(0.035)\end{array}$ & $\begin{array}{c}0.076 * * * \\
(0.023)\end{array}$ & $\begin{array}{c}0.143 * * * \\
(0.046)\end{array}$ \\
\hline \multicolumn{5}{|c|}{ Dependent variable: cognitive skills, age 5} \\
\hline Height-for-age, age 1 & $\begin{array}{c}0.073 * * * \\
(0.021)\end{array}$ & $\begin{array}{c}0.150 * * * \\
(0.021)\end{array}$ & $\begin{array}{c}0.091 * * * \\
(0.026)\end{array}$ & $\begin{array}{c}0.101 * * * \\
(0.023)\end{array}$ \\
\hline Parental investments, age 5 & $\begin{array}{c}0.145 * * * \\
(0.030)\end{array}$ & $\begin{array}{c}0.098 * * * \\
(0.030)\end{array}$ & $\begin{array}{c}0.242 * * * \\
(0.017)\end{array}$ & $\begin{array}{l}0.093 * \\
(0.054)\end{array}$ \\
\hline \multicolumn{5}{|c|}{ Dependent variable: height-for-age, age 8} \\
\hline Cognitive skill, age 5 & $\begin{array}{l}0.057 * \\
(0.033)\end{array}$ & $\begin{array}{c}-0.050 * * \\
(0.024)\end{array}$ & $\begin{array}{c}0.039 * * \\
(0.019)\end{array}$ & $\begin{array}{c}0.047 * * \\
(0.021)\end{array}$ \\
\hline Height-for-age, age 5 & $\begin{array}{c}0.643 * * * \\
(0.035)\end{array}$ & $\begin{array}{c}0.725 * * * \\
(0.025)\end{array}$ & $\begin{array}{c}0.753 * * * \\
(0.019)\end{array}$ & $\begin{array}{c}0.807 * * * \\
(0.045)\end{array}$ \\
\hline Parental investments, age 8 & $\begin{array}{c}0.071 * * * \\
(0.025)\end{array}$ & $\begin{array}{c}0.063 * * * \\
(0.022)\end{array}$ & $\begin{array}{c}0.044 * * * \\
(0.015)\end{array}$ & $\begin{array}{l}0.033 * \\
(0.017)\end{array}$ \\
\hline \multicolumn{5}{|c|}{ Dependent variable: height-for-age, age 5} \\
\hline Height-for-age, age 1 & $\begin{array}{c}0.393 * * * \\
(0.062)\end{array}$ & $\begin{array}{c}0.524 * * * \\
(0.039)\end{array}$ & $\begin{array}{c}0.509 * * * \\
(0.024)\end{array}$ & $\begin{array}{c}0.597 * * * \\
(0.022)\end{array}$ \\
\hline Parental investments, age 5 & $\begin{array}{c}0.027 \\
(0.029) \\
\end{array}$ & $\begin{array}{c}0.114 * * * \\
(0.030)\end{array}$ & $\begin{array}{c}0.076 * * * \\
(0.021)\end{array}$ & $\begin{array}{c}0.106 * * * \\
(0.024)\end{array}$ \\
\hline \multicolumn{5}{|c|}{ PANEL B: total effects of height-for-age at age 1} \\
\hline On cognitive skills, age 8 & $\begin{array}{c}0.053 * * * \\
(0.012)\end{array}$ & $\begin{array}{c}0.090 * * * \\
(0.014)\end{array}$ & $\begin{array}{c}0.076^{* * * *} \\
(0.013)\end{array}$ & $\begin{array}{c}0.084 * * * \\
(0.017)\end{array}$ \\
\hline On non-cognitive skills, age 8 & $\begin{array}{c}0.011 \\
(0.013) \\
\end{array}$ & $\begin{array}{c}0.034 * * * \\
(0.011) \\
\end{array}$ & $\begin{array}{c}0.026 * * \\
(0.012) \\
\end{array}$ & $\begin{array}{c}0.017 \\
(0.013) \\
\end{array}$ \\
\hline $\mathrm{N}$ & 1440 & 1676 & 1661 & 1407 \\
\hline
\end{tabular}

Notes: Consumption expressed in real terms. Non-food consumption includes expenditure in clothes, footwear, education, entertainment, etc, and is expressed in per capita terms. Food consumption is measured at the household level and is expressed in per capita terms. Study hours are reported by the mother and refer to a typical day. Study hours at age 5 refers to the average number of hours of all children in the household when the child was 5 years, whereas the number of study hours at age 8 is specific to the child. 
Table A.2: Model of skill formation: alternative results controlling for wealth index

\begin{tabular}{|c|c|c|c|c|}
\hline & $\begin{array}{l}\text { Ethiopia } \\
\text { (1) }\end{array}$ & $\begin{array}{l}\text { India } \\
(2)\end{array}$ & $\begin{array}{l}\text { Peru } \\
(3)\end{array}$ & $\begin{array}{c}\text { Vietnam } \\
\text { (4) }\end{array}$ \\
\hline \multicolumn{5}{|c|}{ PANEL A } \\
\hline \multicolumn{5}{|c|}{ Dependent variable: cognitive skills, age 8} \\
\hline Cognitive skill, age 5 & $\begin{array}{c}0.119 * * * \\
(0.018)\end{array}$ & $\begin{array}{c}0.224 * * * \\
(0.026)\end{array}$ & $\begin{array}{c}0.240 * * * \\
(0.035)\end{array}$ & $\begin{array}{c}0.193 * * * \\
(0.035)\end{array}$ \\
\hline Height-for-age, age 5 & $\begin{array}{c}0.103 * * * \\
(0.022)\end{array}$ & $\begin{array}{c}0.100 * * * \\
(0.025)\end{array}$ & $\begin{array}{c}0.088 * * * \\
(0.018)\end{array}$ & $\begin{array}{c}0.099 * * * \\
(0.023)\end{array}$ \\
\hline Parental investments, age 8 & $\begin{array}{c}0.218 * * * \\
(0.022)\end{array}$ & $\begin{array}{l}0.080 * * \\
(0.040)\end{array}$ & $\begin{array}{c}0.135 * * * \\
(0.024)\end{array}$ & $\begin{array}{c}0.130 * * * \\
(0.040)\end{array}$ \\
\hline Wealth index, age 8 & $\begin{array}{c}0.151 * * * \\
(0.025)\end{array}$ & $\begin{array}{l}0.118 * * \\
(0.046)\end{array}$ & $\begin{array}{c}0.162 * * * \\
(0.026)\end{array}$ & $\begin{array}{c}0.125 * * * \\
(0.033)\end{array}$ \\
\hline \multicolumn{5}{|c|}{ Dependent variable: non-cognitive skills, age 8} \\
\hline Cognitive skill, age 5 & $\begin{array}{l}-0.040 \\
(0.035)\end{array}$ & $\begin{array}{c}0.093 * * * \\
(0.029)\end{array}$ & $\begin{array}{c}0.096 * * * \\
(0.031)\end{array}$ & $\begin{array}{c}0.125 * * * \\
(0.035)\end{array}$ \\
\hline Height-for-age, age 5 & $\begin{array}{c}0.023 \\
(0.031)\end{array}$ & $\begin{array}{c}0.031 \\
(0.021)\end{array}$ & $\begin{array}{c}0.024 \\
(0.025)\end{array}$ & $\begin{array}{l}-0.001 \\
(0.019)\end{array}$ \\
\hline Parental investments, age 8 & $\begin{array}{c}0.073 \\
(0.052)\end{array}$ & $\begin{array}{c}0.142 * * * \\
(0.034)\end{array}$ & $\begin{array}{l}0.051 * * \\
(0.023)\end{array}$ & $\begin{array}{l}0.112 * * \\
(0.049)\end{array}$ \\
\hline Wealth index, age 8 & $\begin{array}{c}0.161 * * * \\
(0.041)\end{array}$ & $\begin{array}{c}0.108 * * * \\
(0.031)\end{array}$ & $\begin{array}{c}0.090 \\
(0.056)\end{array}$ & $\begin{array}{c}0.134 * * * \\
(0.040)\end{array}$ \\
\hline \multicolumn{5}{|c|}{ Dependent variable: cognitive skills, age 5} \\
\hline Height-for-age, age 1 & $\begin{array}{c}0.062 * * * \\
(0.021)\end{array}$ & $\begin{array}{c}0.149 * * * \\
(0.023)\end{array}$ & $\begin{array}{c}0.073 * * * \\
(0.026)\end{array}$ & $\begin{array}{c}0.095 * * * \\
(0.028)\end{array}$ \\
\hline Parental investments, age 5 & $\begin{array}{c}0.120^{* * *} \\
(0.031)\end{array}$ & $\begin{array}{c}0.096 * * * \\
(0.029)\end{array}$ & $\begin{array}{c}0.174 * * * \\
(0.021)\end{array}$ & $\begin{array}{c}0.068 \\
(0.049)\end{array}$ \\
\hline Wealth index, age 5 & $\begin{array}{c}0.134 * * * \\
(0.046)\end{array}$ & $\begin{array}{c}0.014 \\
(0.035)\end{array}$ & $\begin{array}{c}0.255^{* * * *} \\
(0.039)\end{array}$ & $\begin{array}{c}0.122 * * \\
(0.061)\end{array}$ \\
\hline \multicolumn{5}{|c|}{ Dependent variable: height-for-age, age 8} \\
\hline Cognitive skill, age 5 & $\begin{array}{c}0.050 \\
(0.032)\end{array}$ & $\begin{array}{c}-0.050 * * \\
(0.024)\end{array}$ & $\begin{array}{c}0.026 \\
(0.019)\end{array}$ & $\begin{array}{l}0.042 * * \\
(0.021)\end{array}$ \\
\hline Height-for-age, age 5 & $\begin{array}{c}0.638 * * * \\
(0.038)\end{array}$ & $\begin{array}{c}0.720 * * * \\
(0.027)\end{array}$ & $\begin{array}{c}0.747 * * * \\
(0.020)\end{array}$ & $\begin{array}{c}0.805^{* * * *} \\
(0.047)\end{array}$ \\
\hline Parental investments, age 8 & $\begin{array}{l}0.058^{* *} \\
(0.026)\end{array}$ & $\begin{array}{c}0.049 * * * \\
(0.018)\end{array}$ & $\begin{array}{c}0.037 * * * \\
(0.014)\end{array}$ & $\begin{array}{c}0.020 \\
(0.017)\end{array}$ \\
\hline Wealth index, age 8 & $\begin{array}{c}0.087 * * \\
(0.038)\end{array}$ & $\begin{array}{l}0.062 * \\
(0.032)\end{array}$ & $\begin{array}{c}0.066 * * * \\
(0.026)\end{array}$ & $\begin{array}{c}0.058 * * \\
(0.026)\end{array}$ \\
\hline \multicolumn{5}{|c|}{ Dependent variable: height-for-age, age 5} \\
\hline Height-for-age, age 1 & $\begin{array}{c}0.385^{* * *} * \\
(0.061)\end{array}$ & $\begin{array}{c}0.521 * * * \\
(0.040)\end{array}$ & $\begin{array}{c}0.502 * * * \\
(0.027)\end{array}$ & $\begin{array}{c}0.598 * * * \\
(0.025)\end{array}$ \\
\hline Parental investments, age 5 & $\begin{array}{c}0.012 \\
(0.037)\end{array}$ & $\begin{array}{c}0.086 * * \\
(0.036)\end{array}$ & $\begin{array}{c}0.059 * * \\
(0.025)\end{array}$ & $\begin{array}{c}0.097 * * * \\
(0.025)\end{array}$ \\
\hline Wealth index, age 5 & $\begin{array}{c}0.097 \\
(0.061)\end{array}$ & $\begin{array}{c}0.125 * * * \\
(0.030)\end{array}$ & $\begin{array}{c}0.120 * * * \\
(0.031)\end{array}$ & $\begin{array}{c}0.040 \\
(0.028)\end{array}$ \\
\hline \multicolumn{5}{|c|}{ Dependent variable: height-for-age, age 5} \\
\hline Wealth index, age 1 & $\begin{array}{l}0.181 * * \\
(0.072) \\
\end{array}$ & $\begin{array}{c}0.097 * * * \\
(0.032)\end{array}$ & $\begin{array}{c}0.105^{* *} \\
(0.049) \\
\end{array}$ & $\begin{array}{c}0.176 * * * \\
(0.055) \\
\end{array}$ \\
\hline \multicolumn{5}{|c|}{ PANEL B: total effects of height-for-age at age 1} \\
\hline On cognitive skills, age 8 & $\begin{array}{c}0.047 * * * \\
(0.008)\end{array}$ & $\begin{array}{c}0.086 * * * \\
(0.008)\end{array}$ & $\begin{array}{c}0.062 * * * \\
(0.008)\end{array}$ & $\begin{array}{c}0.077 * * * \\
(0.006)\end{array}$ \\
\hline On non-cognitive skills, age 8 & $\begin{array}{c}0.007 * * * \\
(0.001)\end{array}$ & $\begin{array}{c}0.030 * * * \\
(0.003)\end{array}$ & $\begin{array}{c}0.019 * * * \\
(0.003)\end{array}$ & $\begin{array}{c}0.011^{* * *} * \\
(0.004)\end{array}$ \\
\hline $\mathrm{N}$ & 1440 & 1676 & 1661 & 1407 \\
\hline
\end{tabular}


Table A.3: Model of skill formation: alternative results using a latent factor for nutrition

\begin{tabular}{|c|c|c|c|c|}
\hline & $\begin{array}{l}\text { Ethiopia } \\
\text { (1) }\end{array}$ & $\begin{array}{l}\text { India } \\
(2)\end{array}$ & $\begin{array}{l}\text { Peru } \\
(3)\end{array}$ & $\begin{array}{l}\text { Vietnam } \\
\text { (4) }\end{array}$ \\
\hline \multicolumn{5}{|c|}{ PANEL A } \\
\hline Cognitive skill, age 5 & $\begin{array}{c}0.128 * * * \\
(0.021)\end{array}$ & $\begin{array}{c}0.216 * * * \\
(0.027)\end{array}$ & $\begin{array}{c}0.261 * * * \\
(0.033)\end{array}$ & $\begin{array}{c}0.206 * * * \\
(0.035)\end{array}$ \\
\hline Nutrition, age 5 & $\begin{array}{c}0.101 * * * \\
(0.020)\end{array}$ & $\begin{array}{c}0.134 * * * \\
(0.021)\end{array}$ & $\begin{array}{c}0.099 * * * \\
(0.018)\end{array}$ & $\begin{array}{c}0.104 * * * \\
(0.023)\end{array}$ \\
\hline Parental investments, age 8 & $\begin{array}{c}0.253 * * * \\
(0.024)\end{array}$ & $\begin{array}{c}0.115 * * * \\
(0.037)\end{array}$ & $\begin{array}{c}0.176 * * * \\
(0.026)\end{array}$ & $\begin{array}{c}0.158 * * * \\
(0.042)\end{array}$ \\
\hline \multicolumn{5}{|c|}{ Dependent variable: non-cognitive skills, age 8} \\
\hline Cognitive skill, age 5 & $\begin{array}{l}-0.031 \\
(0.033)\end{array}$ & $\begin{array}{c}0.089 * * * \\
(0.029)\end{array}$ & $\begin{array}{c}0.111 * * * \\
(0.029)\end{array}$ & $\begin{array}{c}0.138 * * * \\
(0.033)\end{array}$ \\
\hline Nutrition, age 5 & $\begin{array}{c}0.026 \\
(0.027)\end{array}$ & $\begin{array}{l}0.036^{*} \\
(0.019)\end{array}$ & $\begin{array}{c}0.008 \\
(0.025)\end{array}$ & $\begin{array}{c}0.005 \\
(0.020)\end{array}$ \\
\hline Parental investments, age 8 & $\begin{array}{c}0.111 * * \\
(0.051)\end{array}$ & $\begin{array}{c}0.177 * * * \\
(0.037)\end{array}$ & $\begin{array}{c}0.078 * * * \\
(0.021)\end{array}$ & $\begin{array}{c}0.142 * * * \\
(0.045)\end{array}$ \\
\hline \multicolumn{5}{|c|}{ Dependent variable: cognitive skills, age 5} \\
\hline Height, age 1 & $\begin{array}{c}0.102 * * * \\
(0.026)\end{array}$ & $\begin{array}{c}0.131 * * * \\
(0.022)\end{array}$ & $\begin{array}{c}0.104 * * * \\
(0.030)\end{array}$ & $\begin{array}{c}0.082 * * * \\
(0.025)\end{array}$ \\
\hline Parental investments, age 5 & $\begin{array}{c}0.142 * * * \\
(0.029)\end{array}$ & $\begin{array}{c}0.097 * * * \\
(0.031)\end{array}$ & $\begin{array}{c}0.234 * * * \\
(0.019)\end{array}$ & $\begin{array}{c}0.096 \\
(0.058)\end{array}$ \\
\hline \multicolumn{5}{|c|}{ Dependent variable: nutrition, age 8} \\
\hline Cognitive skill, age 5 & $\begin{array}{c}0.017 \\
(0.021)\end{array}$ & $\begin{array}{l}-0.015 \\
(0.016)\end{array}$ & $\begin{array}{c}0.014 \\
(0.013)\end{array}$ & $\begin{array}{l}0.042 * * \\
(0.020)\end{array}$ \\
\hline Height, age 5 & $\begin{array}{c}0.766 * * * \\
(0.028)\end{array}$ & $\begin{array}{c}0.780 * * * \\
(0.027)\end{array}$ & $\begin{array}{c}0.830 * * * \\
(0.013)\end{array}$ & $\begin{array}{c}0.829 * * * \\
(0.038)\end{array}$ \\
\hline Parental investments, age 8 & $\begin{array}{c}0.087 * * * \\
(0.025)\end{array}$ & $\begin{array}{c}0.056 * * * \\
(0.015)\end{array}$ & $\begin{array}{c}0.041 * * * \\
(0.013)\end{array}$ & $\begin{array}{l}0.036 * \\
(0.018)\end{array}$ \\
\hline \multicolumn{5}{|c|}{ Dependent variable: health, age 5} \\
\hline Nutrition, age 1 & $\begin{array}{c}0.519 * * * \\
(0.054)\end{array}$ & $\begin{array}{c}0.599 * * * \\
(0.029)\end{array}$ & $\begin{array}{c}0.604 * * * \\
(0.022)\end{array}$ & $\begin{array}{c}0.580 * * * \\
(0.022)\end{array}$ \\
\hline Parental investments, age 5 & $\begin{array}{c}0.032 \\
(0.038) \\
\end{array}$ & $\begin{array}{c}0.083 * * * \\
(0.027) \\
\end{array}$ & $\begin{array}{l}0.051 * * \\
(0.022) \\
\end{array}$ & $\begin{array}{c}0.111 * * * \\
(0.024)\end{array}$ \\
\hline \multicolumn{5}{|c|}{ PANEL B: total effects of nutrition at age 1} \\
\hline On cognitive skills, age 8 & $\begin{array}{c}0.065 * * * \\
(0.008)\end{array}$ & $\begin{array}{c}0.108 * * * \\
(0.006)\end{array}$ & $\begin{array}{c}0.087 * * * \\
(0.011)\end{array}$ & $\begin{array}{c}0.077 * * * \\
(0.006)\end{array}$ \\
\hline On non-cognitive skills, age 8 & $\begin{array}{c}0.010 * * * \\
(0.001)\end{array}$ & $\begin{array}{c}0.033 * * * \\
(0.002)\end{array}$ & $\begin{array}{c}0.016 * * * \\
(0.004)\end{array}$ & $\begin{array}{c}0.014 * * * \\
(0.004)\end{array}$ \\
\hline $\mathrm{N}$ & 1440 & 1676 & 1661 & 1407 \\
\hline
\end{tabular}




\section{Supplementary Material: Part B}

The following seven linear latent factor models were estimated for each country sample. For cognitive skills at age 8 ,

$$
\begin{aligned}
& \operatorname{PPVT}_{8 y}=\alpha_{11, C, 8 y}+\alpha_{21, C, 8 y} * \theta_{8 y}^{C}+\epsilon_{11, C, 8 y} \\
& \text { Math }_{8 y}=\alpha_{12, C, 8 y}+\alpha_{22, C, 8 y} * \theta_{8 y}^{C}+\epsilon_{12, C, 8 y} \\
& E_{\text {GRA }}=\alpha_{13, C, 8 y}+\alpha_{23, C, 8 y} * \theta_{8 y}^{C}+\epsilon_{13, C, 8 y}
\end{aligned}
$$

For cognitive skills at age 5,

$$
\begin{gathered}
P P V T_{5 y}=\alpha_{11, C, 5 y}+\alpha_{21, C, 5 y} * \theta_{5 y}^{C}+\epsilon_{11, C, 5 y} \\
C D A_{5 y}=\alpha_{12, C, 5 y}+\alpha_{22, C, 5 y} * \theta_{5 y}^{C}+\epsilon_{12, C, 5 y}
\end{gathered}
$$

For non-cognitive skills at age 8 ,

$$
\begin{gathered}
\text { SelfEsteem }_{8 y}=\alpha_{11, N, 8 y}+\alpha_{21, N, 8 y} * \theta_{8 y}^{N}+\epsilon_{11, N, 8 y} \\
\text { SelfEfficacy } y_{8 y}=\alpha_{12, N, 8 y}+\alpha_{22, N, 8 y} * \theta_{8 y}^{N}+\epsilon_{12, N, 8 y}
\end{gathered}
$$

For parental investments in skills at age 8,

$$
\begin{gathered}
\text { ExpenditureClothes }_{8 y}=\alpha_{11, I, 8 y}+\alpha_{21, I, 8 y} * I_{8 y}+\epsilon_{11, I, 8 y} \\
\text { ExpenditureEducation }{ }_{8 y}=\alpha_{12, I, 8 y}+\alpha_{22, I, 8 y} * I_{8 y}+\epsilon_{12, I, 8 y} \\
\text { HoursStudy } y_{8 y}=\alpha_{13, I, 8 y}+\alpha_{23, I, 8 y} * I_{8 y}+\epsilon_{13, I, 8 y} \\
\text { RelationshipParents } s_{8 y}=\alpha_{14, I, 8 y}+\alpha_{24, I, 8 y} * I_{8 y}+\epsilon_{14, I, 8 y}
\end{gathered}
$$

For parental investments in skills at age 5,

$$
\begin{gathered}
\text { ExpenditureClothes }_{5 y}=\alpha_{11, I, 5 y}+\alpha_{21, I, 5 y} * I_{5 y}+\epsilon_{11, I, 5 y} \\
\text { ExpenditureEducation }_{5 y}=\alpha_{12, I, 5 y}+\alpha_{22, I, 5 y} * I_{5 y}+\epsilon_{12, I, 5 y} \\
\text { AverageHoursStudy }_{5 y}=\alpha_{13, I, 5 y}+\alpha_{23, I, 5 y} * I_{5 y}+\epsilon_{13, I, 5 y}
\end{gathered}
$$

Finally, for parental investments in nutrition (where k represents ages 5 and 8),

$$
\begin{gathered}
\text { ConsumptionCarbohydrates } s_{k}=\alpha_{11, H, k}+\alpha_{21, H, k} * I_{k}^{H}+\epsilon_{11, H, k} \\
\text { ConsumptionProteins }{ }_{k}=\alpha_{12, H, k}+\alpha_{22, H, k} * I_{k}^{H}+\epsilon_{12, H, k} \\
\text { ConsumptionMineralsVitamins } s_{5 y}=\alpha_{13, H, k}+\alpha_{23, H, k} * I_{k}^{H}+\epsilon_{13, H, k} \\
\text { ConsumptionLipids }{ }_{5 y}=\alpha_{14, H, k}+\alpha_{24, H, k} * I_{k}^{H}+\epsilon_{14, H, k}
\end{gathered}
$$

In models with more than two observable indicators, the first factor loading was set to 1, whereas in models with two observable indicators, factor loadings were assumed to be equal. Models were estimated using the SEM command in STATA. Joint normality of observable and factors in each model was assumed. 
Table B.1: Factor loadings

\begin{tabular}{|c|c|c|c|}
\hline & Variable & Coefficient & Standard error \\
\hline \multicolumn{4}{|c|}{ Cognitive skills, age 8} \\
\hline \multirow{3}{*}{ Ethiopia } & PPVT & 1.00 & 0.51 \\
\hline & Maths test & 1.28 & 0.18 \\
\hline & EGRA & 1.07 & 0.42 \\
\hline \multirow[t]{3}{*}{ India } & PPVT & 1.00 & 0.66 \\
\hline & Maths test & 1.47 & 0.27 \\
\hline & EGRA & 1.33 & 0.40 \\
\hline \multirow[t]{3}{*}{ Peru } & PPVT & 1.00 & 0.35 \\
\hline & Maths test & 0.99 & 0.37 \\
\hline & EGRA & 1.02 & 0.32 \\
\hline \multirow[t]{3}{*}{ Vietnam } & PPVT & 1.00 & 0.61 \\
\hline & Maths test & 1.28 & 0.40 \\
\hline & EGRA & 1.03 & 0.53 \\
\hline \multicolumn{4}{|c|}{ Cognitive skills, age 5} \\
\hline \multirow{2}{*}{ Ethiopia } & PPVT & 0.69 & 0.54 \\
\hline & CDA & 0.69 & 0.49 \\
\hline \multirow[t]{2}{*}{ India } & $\overline{\text { PPVT }}$ & 0.69 & 0.55 \\
\hline & CDA & 0.69 & 0.50 \\
\hline \multirow[t]{2}{*}{ Peru } & PPVT & 0.75 & 0.50 \\
\hline & CDA & 0.75 & 0.43 \\
\hline \multirow[t]{2}{*}{ Vietnam } & PPVT & 0.77 & 0.48 \\
\hline & CDA & 0.77 & 0.44 \\
\hline \multicolumn{4}{|c|}{ Non-cognitive skills, age 8} \\
\hline \multirow[t]{2}{*}{ Ethiopia } & Self-esteem & 0.60 & 0.73 \\
\hline & Self-efficacy & 0.60 & 0.73 \\
\hline \multirow[t]{2}{*}{ India } & Self-esteem & 0.69 & 0.63 \\
\hline & Self-efficacy & 0.69 & 0.63 \\
\hline \multirow[t]{2}{*}{ Peru } & Self-esteem & 0.75 & 0.60 \\
\hline & Self-efficacy & 0.75 & 0.60 \\
\hline \multirow[t]{2}{*}{ Vietnam } & Self-esteem & 0.68 & 0.69 \\
\hline & Self-efficacy & 0.68 & 0.69 \\
\hline \multicolumn{4}{|c|}{ Parental investments in skills, age 8} \\
\hline \multirow[t]{4}{*}{ Ethiopia } & Log expenditure on children's education & 1.00 & 0.82 \\
\hline & Log expenditure on children's clothes & 3.63 & 0.40 \\
\hline & Number of hours child studies outside school & 0.72 & 0.68 \\
\hline & Quality of relationship between child and parents & 0.00 & 0.03 \\
\hline \multirow[t]{4}{*}{ India } & Log expenditure on children's education & 1.00 & 0.36 \\
\hline & Log expenditure on children's clothes & 2.34 & 0.80 \\
\hline & Number of hours child studies outside school & 0.81 & 1.04 \\
\hline & Quality of relationship between child and parents & 0.03 & 0.04 \\
\hline \multirow[t]{4}{*}{ Peru } & Log expenditure on children's education & 1.00 & 0.95 \\
\hline & Log expenditure on children's clothes & 1.49 & 0.22 \\
\hline & Number of hours child studies outside school & 0.38 & 0.63 \\
\hline & Quality of relationship between child and parents & 0.03 & 0.02 \\
\hline \multirow[t]{3}{*}{ Vietnam } & Log expenditure on children's clothes and education & 1.00 & 0.68 \\
\hline & Number of hours child studies outside school & 2.15 & 1.11 \\
\hline & Quality of relationship between child and parents & 0.07 & 0.03 \\
\hline
\end{tabular}

(continues in next page...) 


\begin{tabular}{|c|c|c|c|}
\hline \multicolumn{2}{|r|}{ Variable } & Coefficient & Standard error \\
\hline \multicolumn{4}{|c|}{ Parental investments in skills, age 5} \\
\hline \multirow[t]{3}{*}{ Ethiopia } & Log expenditure on children's clothes & 1.00 & 0.92 \\
\hline & Log expenditure on children's education & 5.26 & 0.44 \\
\hline & Average number of hours children study outside school & 1.06 & 0.55 \\
\hline \multirow[t]{3}{*}{ India } & Log expenditure on children's clothes & 1.00 & 0.57 \\
\hline & Log expenditure on children's education & 5.34 & 0.26 \\
\hline & Average number of hours children study outside school & 1.08 & 1.15 \\
\hline \multirow[t]{3}{*}{ Peru } & Log expenditure on children's clothes & 1.00 & 1.75 \\
\hline & Log expenditure on children's education & 2.60 & 0.39 \\
\hline & Average number of hours children study outside school & 0.55 & 0.51 \\
\hline \multirow[t]{3}{*}{ Vietnam } & Log expenditure on children's clothes & 1.00 & 0.82 \\
\hline & Log expenditure on children's education & 6.01 & 1.03 \\
\hline & Average number of hours children study outside school & 1.28 & 1.06 \\
\hline \multicolumn{4}{|c|}{ Parental investments in nutrition, age 5} \\
\hline \multirow[t]{4}{*}{ Ethiopia } & Log consumption of proteins & 1.00 & 1.19 \\
\hline & Log consumption of carbohydrates & 0.91 & 0.29 \\
\hline & Log consumption of lipids and other food types & 1.68 & 0.25 \\
\hline & Log consumption of minerals and vitamins & 0.63 & 1.05 \\
\hline \multirow[t]{4}{*}{ India } & Log consumption of proteins & 1.00 & 0.58 \\
\hline & Log consumption of carbohydrates & 0.68 & 0.26 \\
\hline & Log consumption of lipids and other food types & 0.84 & 0.09 \\
\hline & Log consumption of minerals and vitamins & 0.88 & 0.22 \\
\hline \multirow[t]{4}{*}{ Peru } & Log consumption of proteins & 1.00 & 0.33 \\
\hline & Log consumption of carbohydrates & 0.45 & 0.13 \\
\hline & Log consumption of lipids and other food types & 0.61 & 0.15 \\
\hline & Log consumption of minerals and vitamins & 0.89 & 0.44 \\
\hline \multirow[t]{4}{*}{ Vietnam } & Log consumption of proteins & 1.00 & 0.23 \\
\hline & Log consumption of carbohydrates & 0.25 & 0.16 \\
\hline & Log consumption of lipids and other food types & 0.53 & 0.22 \\
\hline & Log consumption of minerals and vitamins & 0.80 & 0.31 \\
\hline \multicolumn{4}{|c|}{ Parental investments in nutrition, age 8} \\
\hline \multirow[t]{4}{*}{ Ethiopia } & Log consumption of proteins & 1.00 & 0.96 \\
\hline & Log consumption of carbohydrates & 1.29 & 0.32 \\
\hline & Log consumption of lipids and other food types & 1.94 & 0.15 \\
\hline & Log consumption of minerals and vitamins & 1.25 & 1.40 \\
\hline \multirow[t]{4}{*}{ India } & Log consumption of proteins & 1.00 & 0.44 \\
\hline & Log consumption of carbohydrates & 1.00 & 0.22 \\
\hline & Log consumption of lipids and other food types & 0.91 & 0.12 \\
\hline & Log consumption of minerals and vitamins & 0.86 & 0.22 \\
\hline \multirow[t]{4}{*}{ Peru } & Log consumption of proteins & 1.00 & 0.27 \\
\hline & Log consumption of carbohydrates & 0.64 & 0.12 \\
\hline & Log consumption of lipids and other food types & 0.77 & 0.25 \\
\hline & Log consumption of minerals and vitamins & 0.97 & 0.34 \\
\hline \multirow[t]{4}{*}{ Vietnam } & Log consumption of proteins & 1.00 & 0.32 \\
\hline & Log consumption of carbohydrates & 0.58 & 0.21 \\
\hline & Log consumption of lipids and other food types & 0.67 & 0.20 \\
\hline & Log consumption of minerals and vitamins & 0.96 & 0.28 \\
\hline
\end{tabular}


Table B.2: Spearman's rank correlation matrix

\begin{tabular}{lccccccc}
\hline & Cog & Non-Cog & Cog & Inv. & Inv. & Inv. & Inv. \\
& Skills & Skills & Skills & Skills & Skills & Nut. & Nut. \\
& $8 \mathrm{y}$ & $8 \mathrm{y}$ & $5 \mathrm{y}$ & $8 \mathrm{y}$ & $5 \mathrm{y}$ & $8 \mathrm{y}$ & $5 \mathrm{y}$ \\
\hline Ethiopia & & & & & & &
\end{tabular}

Cog. skills, $8 \mathrm{y}$

Non-cog.skills, 8y

Cog. skills, $5 y$

1
$0.24 * * *$

$0.42 * * *$

$0.56 * * *$

$0.47 * * *$

$0.38 * * *$

$0.36 * * *$

$0.30 * * *$

$0.33 * * *$

$0.17 * * *$

Height, 1y

\section{India}

Cog. skills, $8 \mathrm{y}$

Non-cog.skills, $8 \mathrm{y}$

Cog. skills, $5 \mathrm{y}$

Inv. in skills, $8 \mathrm{y}$

Inv. in skills, $5 y$

Inv. in nut., $8 \mathrm{y}$

Inv. in nut, $5 y$

Height, 8y

Height, 5y

Height, 1y

Peru

Cog. skills, 8y

Non-cog.skills, 8y

Cog. skills, $5 \mathrm{y}$

Inv. in skills, 8y

Inv. in skills, $5 y$

Inv. in nut., $8 \mathrm{y}$

Inv. in nut, $5 y$

Height, 8y

Height, 5y

Height, 1y

Vietnam

Cog. skills, 8y

Non-cog.skills, 8y

Cog. skills, $5 \mathrm{y}$

Inv. in skills, $8 \mathrm{y}$

Inv. in skills, $5 y$

Inv. in nut., $8 \mathrm{y}$

Inv. in nut, $5 y$

Height, 8y

Height, 5y

Height, 1y

$$
1
$$

$0.23 * * *$

$0.35 * * *$

$0.25 * * *$

$0.25 * * *$

$0.09 * * *$

$0.07 * * *$

$0.27 * * *$

$0.24 * * *$

$0.28 * * *$

\section{1}

$0.09 * * *$

$0.2 * * *$

$0.13 * * *$

$0.17 * * *$

$0.23 * * *$

$0.08 * * *$

$0.07 * * *$

0.01

1
$0.22 * * *$
$0.24 * * *$
$0.28 * * *$
$0.08 * * *$
$0.14 * * *$
$0.18 * * *$
$0.14 * * *$
$0.11 * * *$

1

$0.28 * * *$

$0.30 * * * \quad 0.53 * * *$

$0.11 * * * \quad 0.44 * * *$

$0.11 * * * \quad 0.29 * * *$

$0.19 * * * \quad 0.21 * * *$

$0.23 * * * \quad 0.17 * * *$

$0.20 * * *$

$0.19 * * *$

1
$0.21 * * *$

$0.33 * * *$

$0.31 * * *$

$0.28 * * *$

$0.20 * * *$

1

$0.30 * * *$

$0.07 * * *$

0.04

0.02

$0.12 * * *$

0.03

Notes: Variables are standardized to have mean zero and variance one.* indicates significance at $10 \%$; $* *$ at $5 \% ; * * *$ at $1 \%$. 


\begin{tabular}{|c|c|c|c|c|}
\hline & $\begin{array}{c}\text { Ethiopia } \\
\text { (1) }\end{array}$ & $\begin{array}{l}\text { India } \\
\text { (2) }\end{array}$ & $\begin{array}{c}\text { Peru } \\
\text { (3) }\end{array}$ & $\begin{array}{c}\text { Vietnam } \\
\text { (4) }\end{array}$ \\
\hline \multicolumn{5}{|l|}{ PART A } \\
\hline \multicolumn{5}{|c|}{ Dep variable: height, age 5} \\
\hline \multicolumn{5}{|c|}{ Endogenous variables: height at age 1, parental investments at age 5} \\
\hline Kelibergen-Pap rk Wald F statistic & 15.2 & 28.6 & 2.6 & 22.9 \\
\hline \multicolumn{5}{|c|}{ Dep variable: cognitive skills, age 5} \\
\hline \multicolumn{5}{|c|}{ Endogenous variables: height at age 1 , parental investments at age 5} \\
\hline Kelibergen-Pap rk Wald F statistic & 26.7 & 17.2 & 5.8 & 5.4 \\
\hline \multicolumn{5}{|c|}{ Stock-Yogo weak ID test critical values } \\
\hline $5 \%$ maximal IV relative bias & 20.2 & 20.0 & 19.4 & 19.8 \\
\hline $10 \%$ maximal IV relative bias & 11.0 & 10.9 & 10.8 & 10.9 \\
\hline $20 \%$ maximal IV relative bias & 6.2 & 6.2 & 6.2 & 6.2 \\
\hline \multicolumn{5}{|l|}{ PART B } \\
\hline \multicolumn{5}{|c|}{ Cognitive skills, age 8} \\
\hline \multicolumn{5}{|c|}{ Endogenous variables: parental investments at age 8} \\
\hline Kelibergen-Pap rk Wald F statistic & 3.7 & 11.6 & 3.5 & 2.7 \\
\hline \multicolumn{5}{|c|}{ Non-cognitive skills, age 8} \\
\hline \multicolumn{5}{|c|}{ Endogenous variables: parental investments at age 8} \\
\hline Kelibergen-Pap rk Wald F statistic & 6.4 & 10.1 & 2.7 & 2.3 \\
\hline \multicolumn{5}{|c|}{ Height, age 8} \\
\hline \multicolumn{5}{|c|}{ Endogenous variables: parental investments at age 8} \\
\hline Kelibergen-Pap rk Wald F statistic & 6.7 & 2.0 & 4.9 & 12.0 \\
\hline \multicolumn{5}{|c|}{ Stock-Yogo weak ID test critical values } \\
\hline $5 \%$ maximal IV relative bias & 21.1 & 20.7 & 19.9 & 21.0 \\
\hline $10 \%$ maximal IV relative bias & 11.5 & 11.5 & 11.3 & 11.5 \\
\hline $20 \%$ maximal IV relative bias & 6.5 & 6.6 & 6.7 & 6.53 \\
\hline
\end{tabular}

Note: in Part B, I assume that height at age 1 and parental investments at age 5 are exogenous 
Figure 1: Distribution of cognitive skills and non-cognitive skills (by country) Ethiopia

Age 5

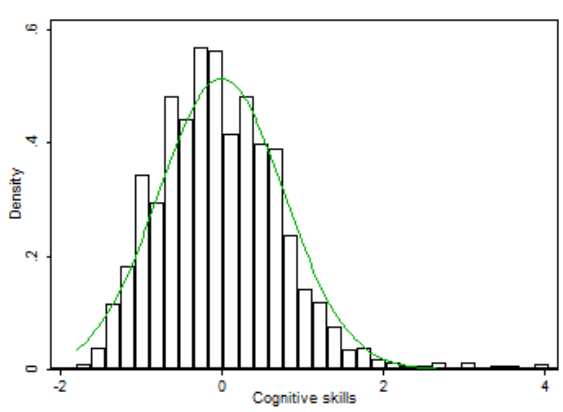

Age 5

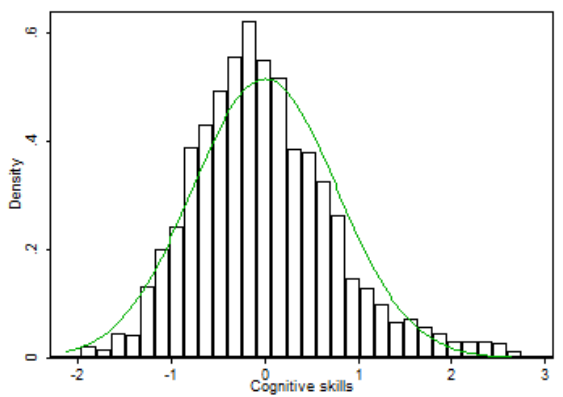

Age 5

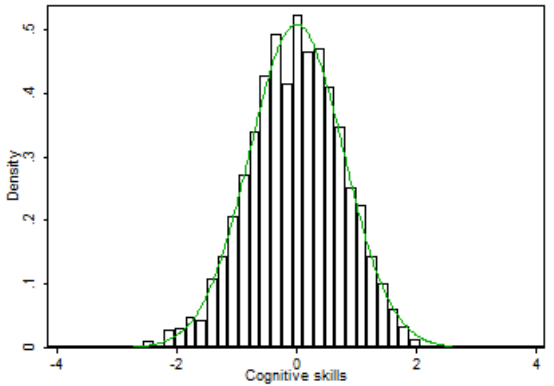

Age 5

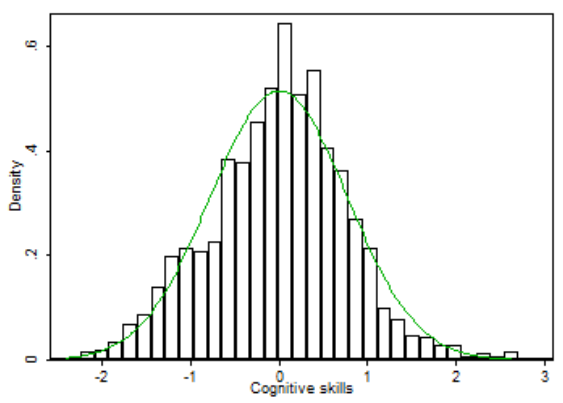

Age 8

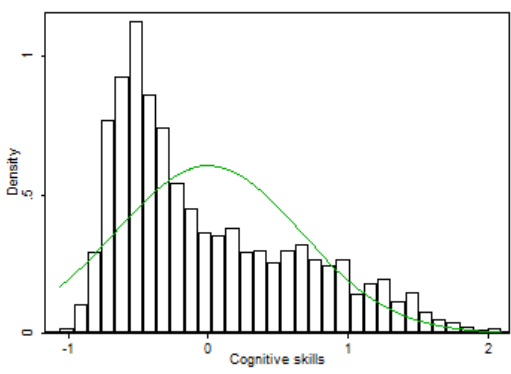

India

Age 8

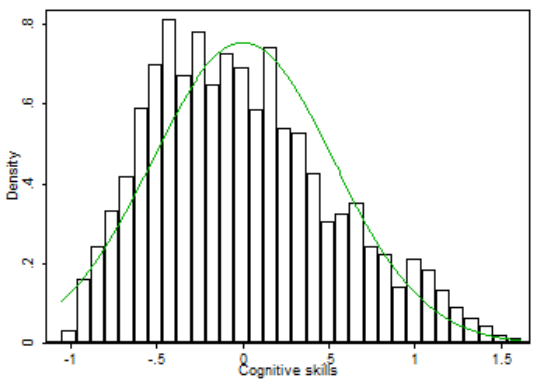

Peru

Age 8

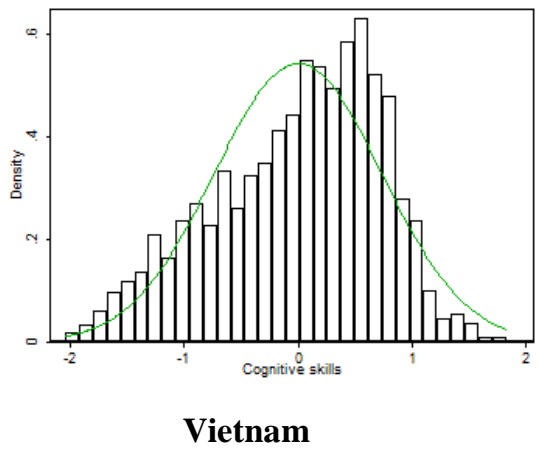

Age 8

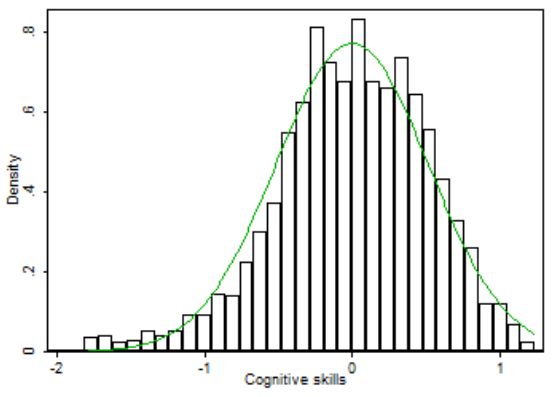

Age 8

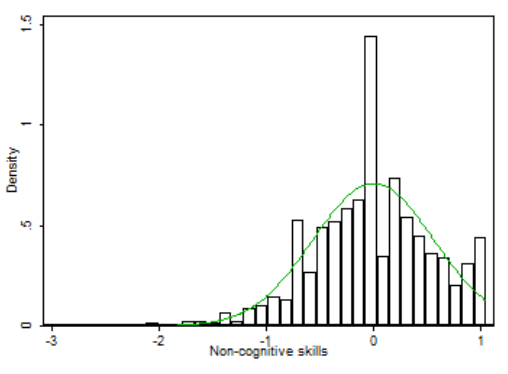

Age 8

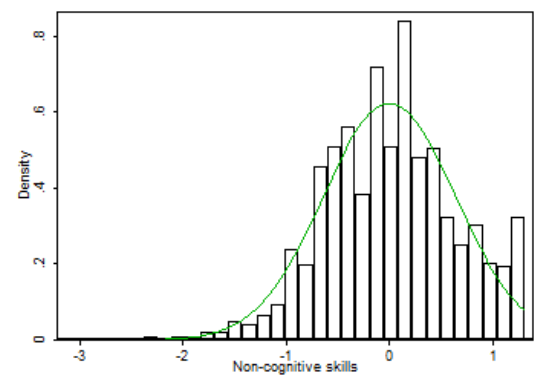

Age 8

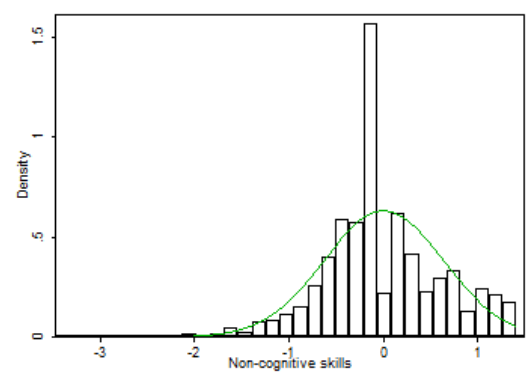

Age 8

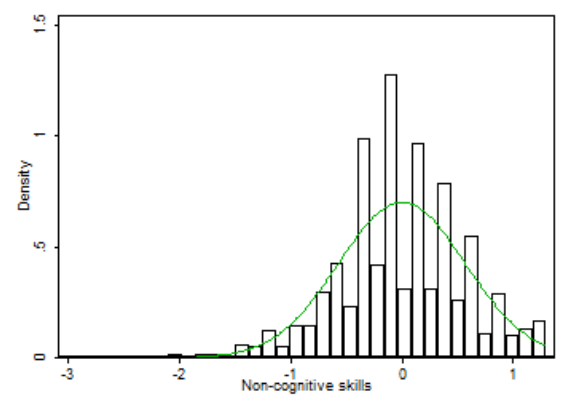


Figure 2: Distribution of latent health (by country) Ethiopia

Age 1

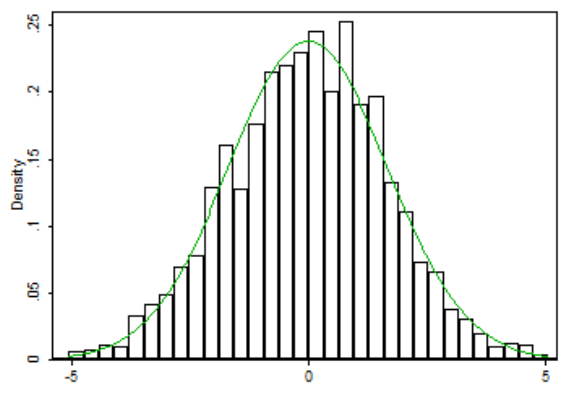

Age 1

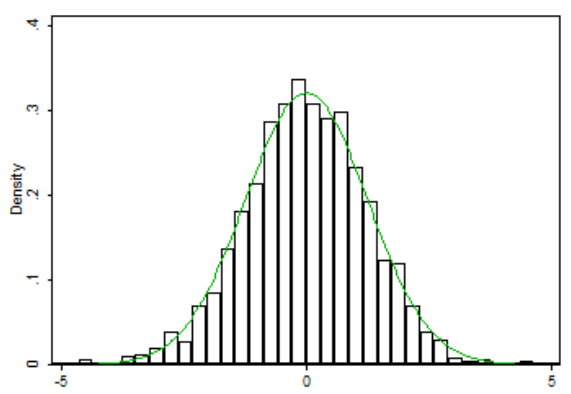

Age 1

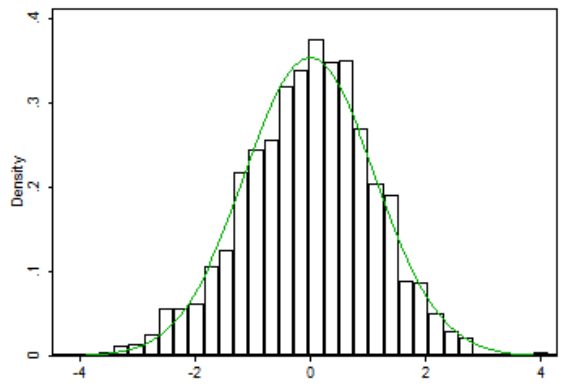

Age 1

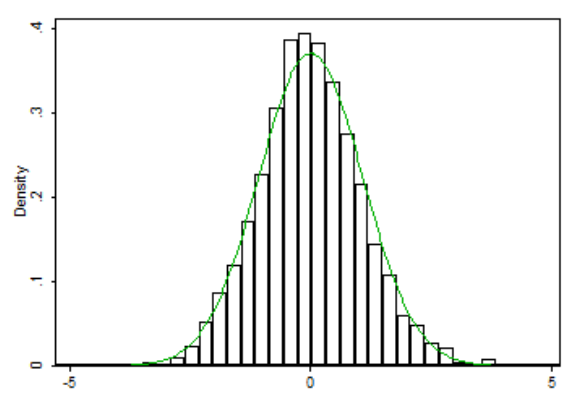

Age 5

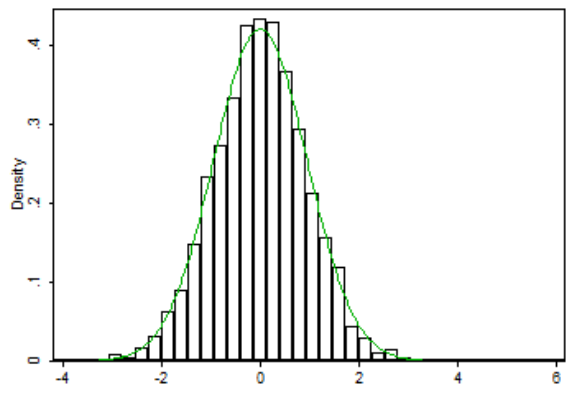

India

Age 5

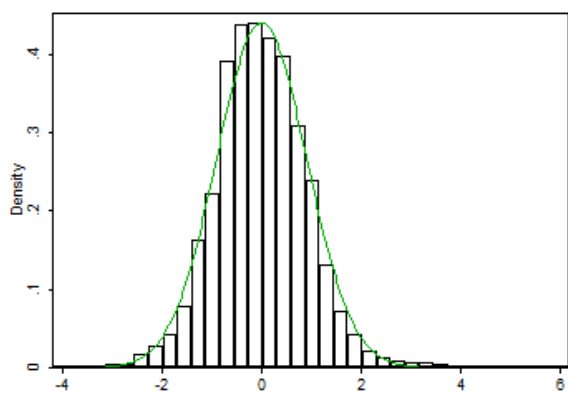

Peru

Age 5

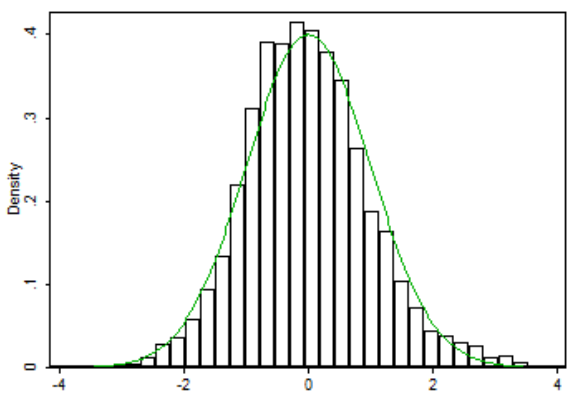

Vietnam

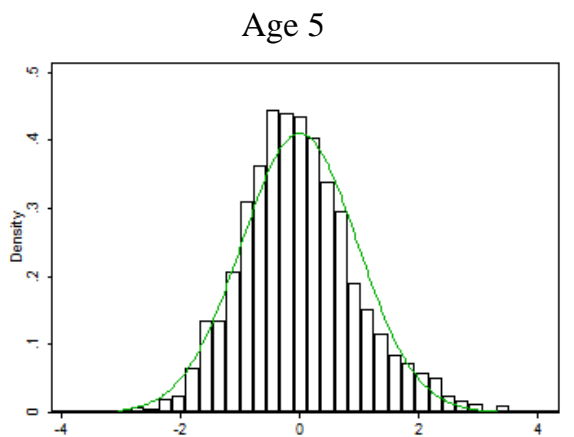

Age 8

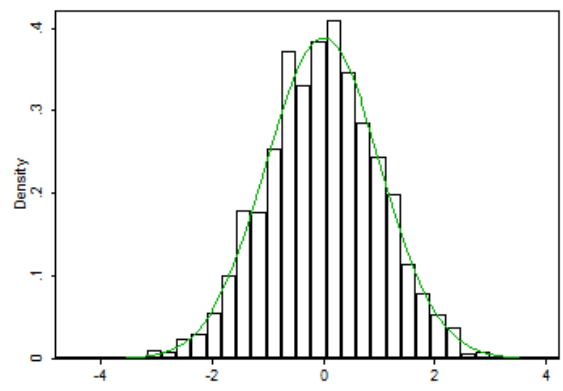

Age 8

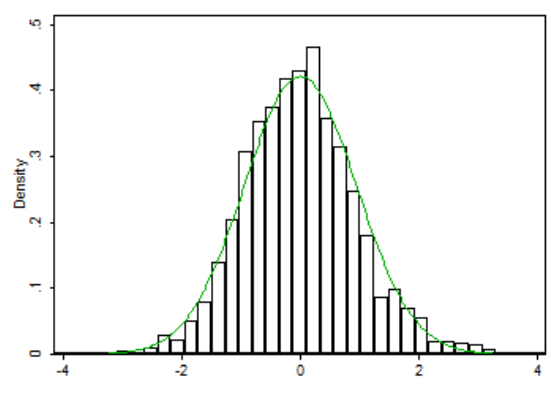

Age 8

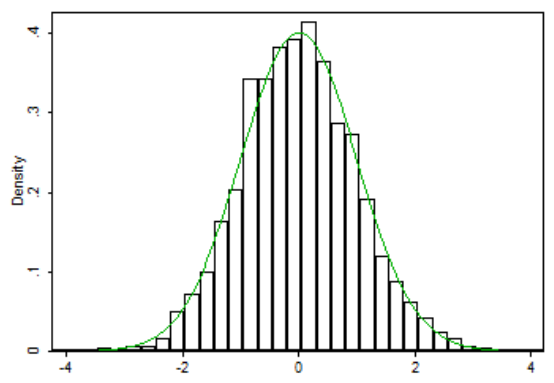

Age 8

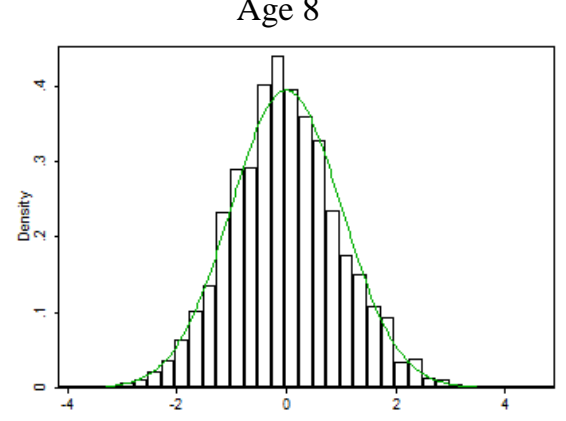


Figure 3: Distribution of parental investments in skills (by country) Ethiopia
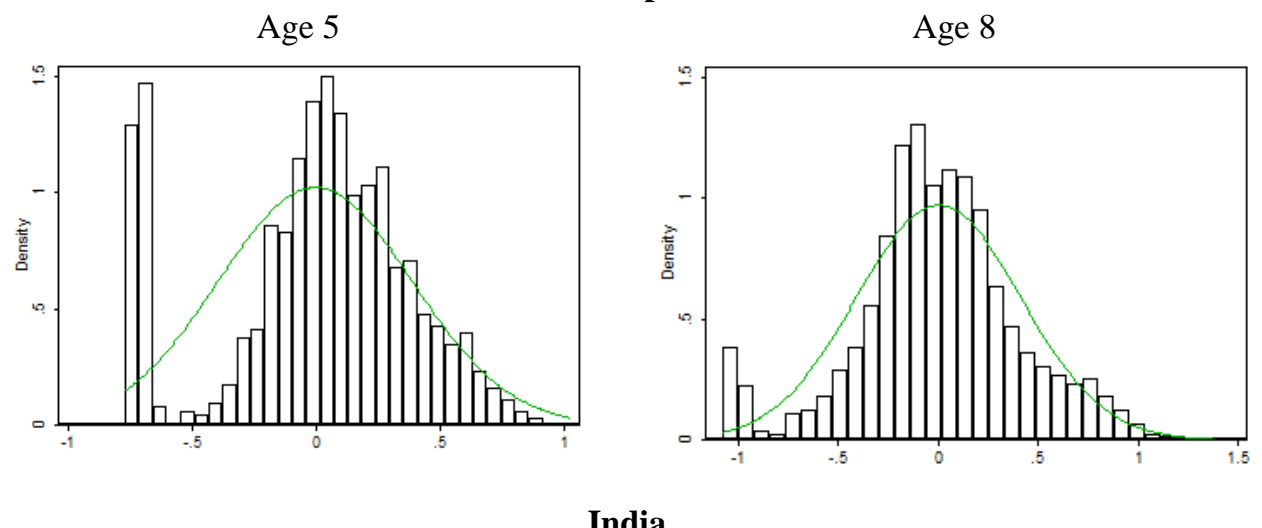

Age 5

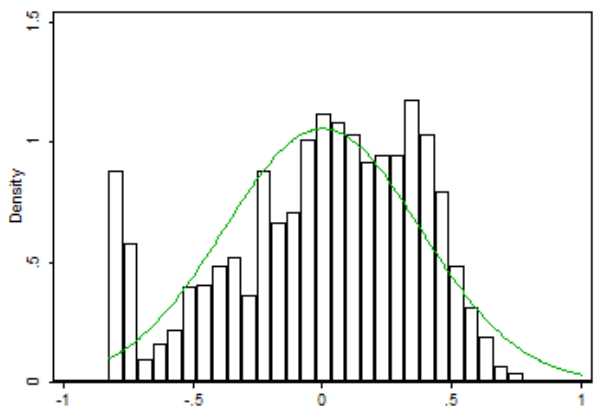

Age 8

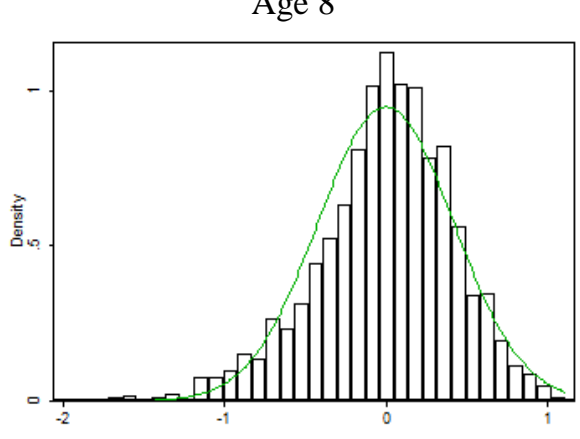

Peru
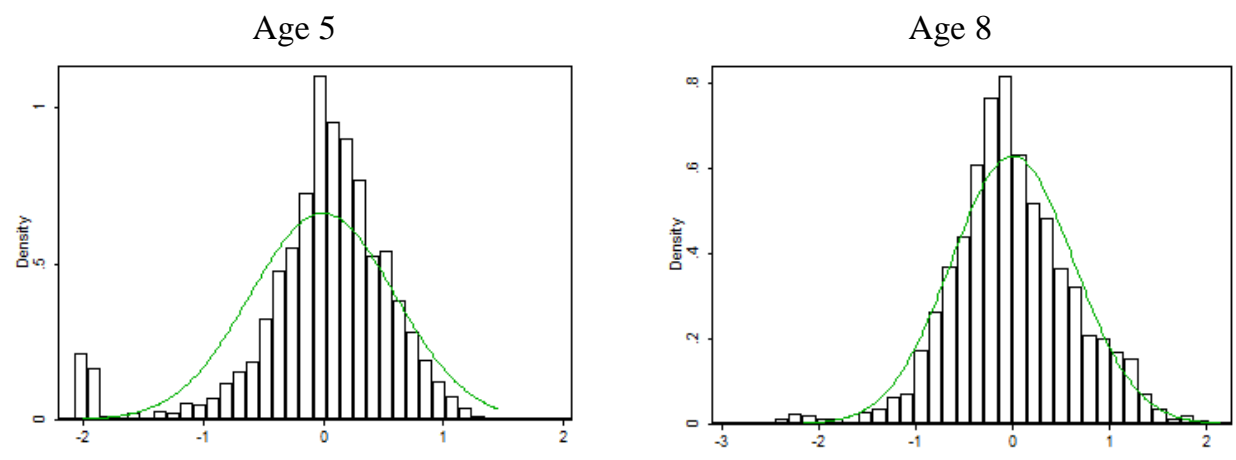

Vietnam

Age 5

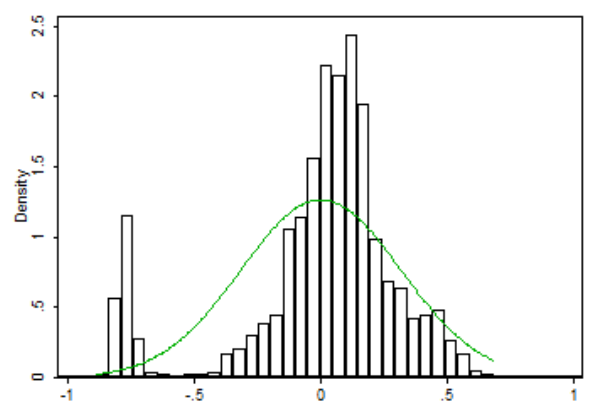

Age 8

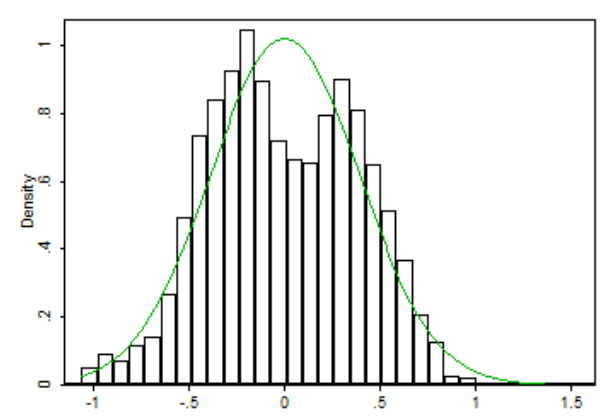


Figure 4: Distribution of parental investments in nutrition (by country) Ethiopia
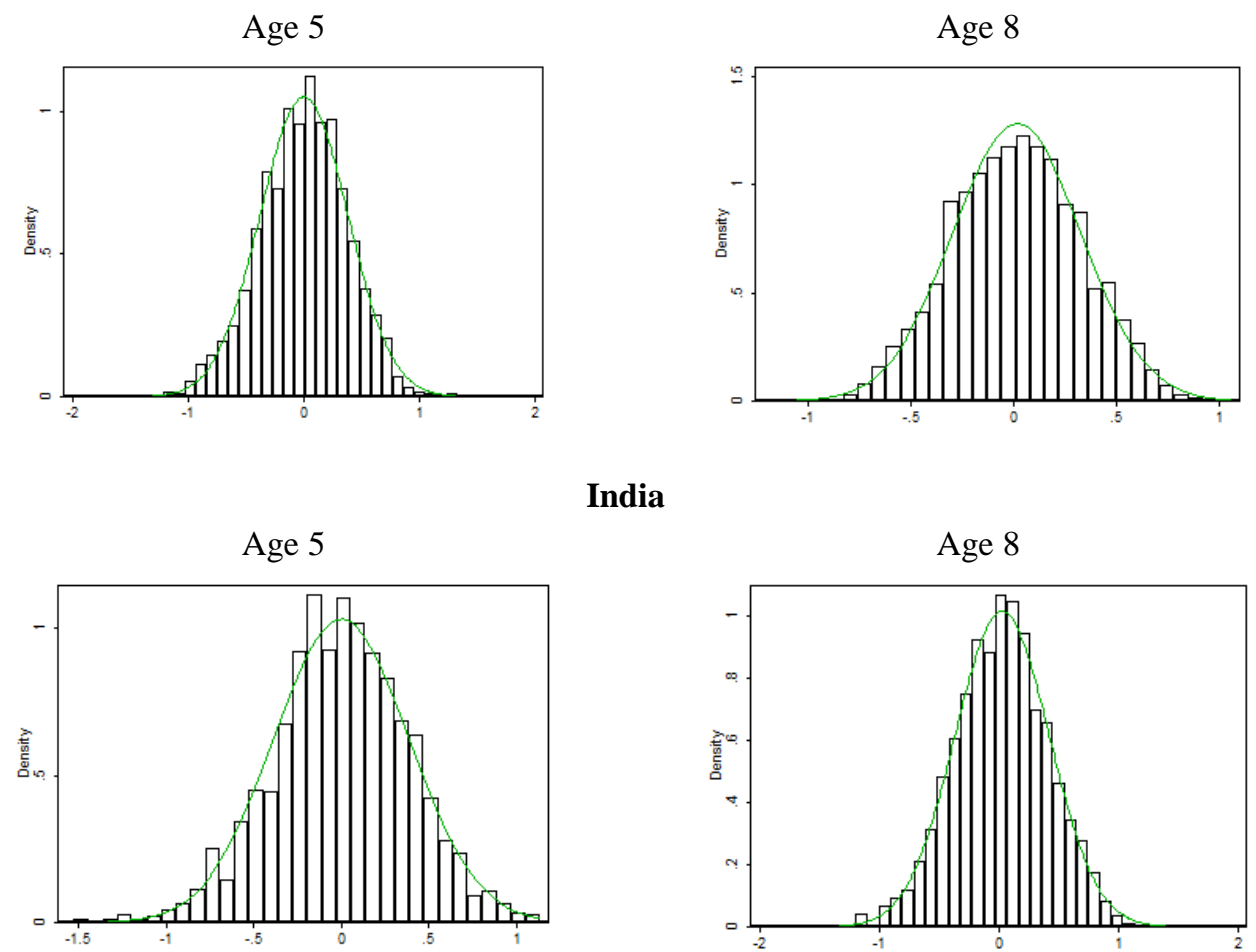

Peru

Age 5
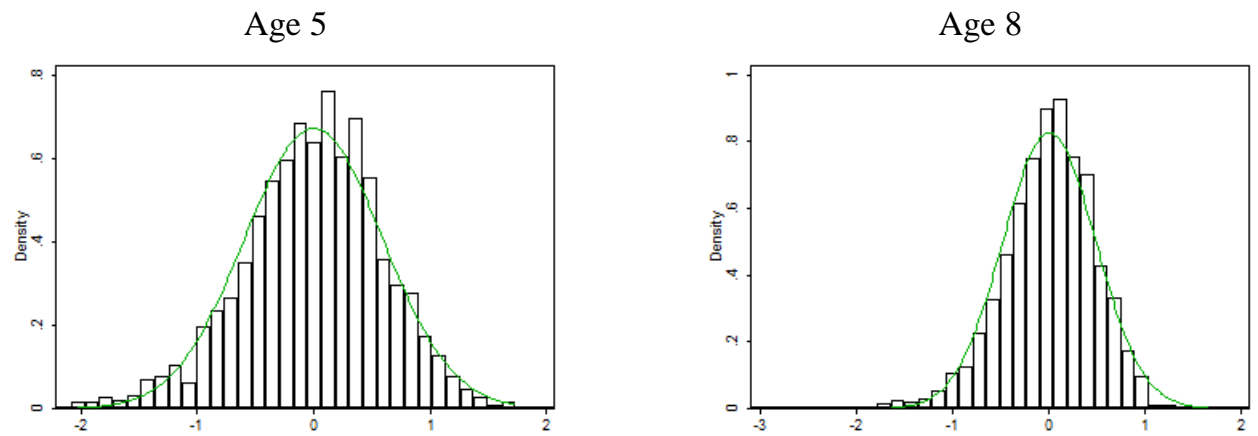

Vietnam

Age 5

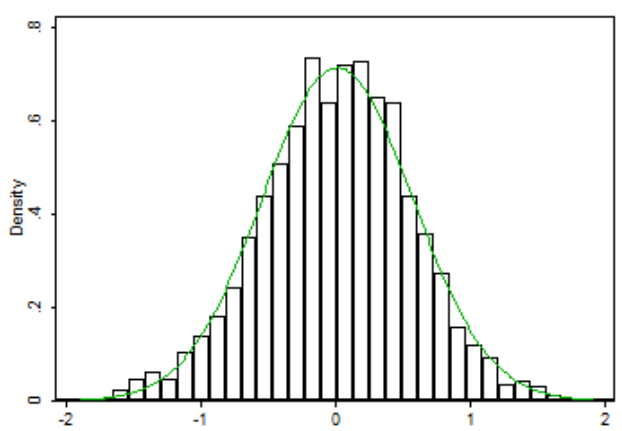

Age 8

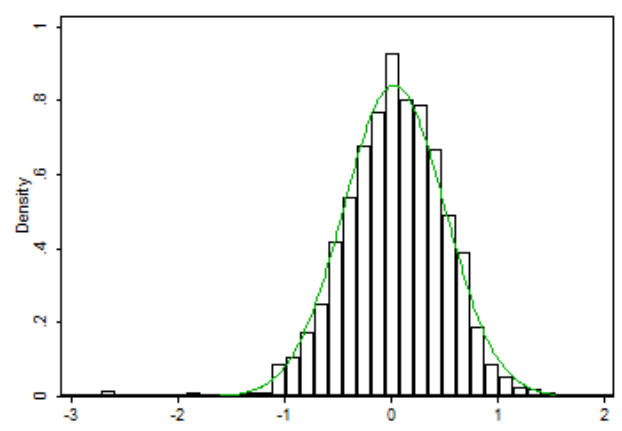

